Journal of

Molecular Microbiology

and Biotechnology

\title{
Bacterial Metabolism of Polychlorinated Biphenyls
}

\author{
Dietmar H. Pieper ${ }^{a} \quad$ Michael Seeger $^{b}$ \\ a Biodegradation Research Group, Division of Microbiology, HZI, Helmholtz Centre for Infection Research, \\ Braunschweig, Germany; ${ }^{b}$ Laboratorio de Microbiología Molecular y Biotecnología Ambiental, Departamento de \\ Química and Millennium Nucleus of Microbial Ecology and Environmental Microbiology and Biotechnology, \\ Universidad Técnica Federico Santa María, Valparaíso, Chile
}

\section{Key Words}

Polychlorinated biphenyls • Reductive dehalogenation • Metabolism • Rieske non-heme iron oxygenases

\begin{abstract}
Microbial metabolism is responsible for the removal of persistent organic pollutants including PCBs from the environment. Anaerobic dehalogenation of highly chlorinated congeners in aquatic sediments is an important process, and recent evidence has indicated that Dehalococcoides and related organisms are predominantly responsible for this process. Such anaerobic dehalogenation generates lower chlorinated congeners which are easily degraded aerobically by enzymes of the biphenyl upper pathway (bph). Initial biphenyl 2,3-dioxygenases are generally considered the key enzymes of this pathway which determine substrate range and extent of $P C B$ degradation. These enzymes have been subject to different protein evolution strategies, and subsequent enzymes have been considered as crucial for metabolism. Significant advances have been made regarding the mechanistic understanding of these enzymes, which has also included elucidation of the function of BphK glutathione transferase. So far, the genomes of two important PCB-metabolizing organisms, namely Burkholderia xenovorans strain LB400 and Rhodococcus sp. strain RHA1, have been sequenced, with the rational to better understand their overall physiology and evolution. Genomic and proteomic analysis also allowed a better evalua-
\end{abstract}

tion of PCB toxicity. Like all bph gene clusters which have been characterized in detail, particularly in strains LB400 and RHA1, these genes were localized on mobile genetic elements endowing single strains and microbial communities with a high flexibility and adaptability. However, studies show that our knowledge on enzymes and genes involved in PCB metabolism is still rather fragmentary and that the diversity of bacterial strategies is highly underestimated. Overall, metabolism of biphenyl and PCBs should not be regarded as a simple linear pathway, but as a complex interplay between different catabolic gene modules.

Copyright $\odot 2008$ S. Karger AG, Basel

\section{Introduction}

The concern about environmental pollution with persistent organic pollutants is increasing due their toxicity, bioaccumulation, extensive distribution and recalcitrance. Polychlorinated biphenyls (PCBs) are a class of compounds which have been used since 1929 for various industrial and commercial purposes such as dielectric, heat transfer, hydraulic fluids, plasticizers and fire retardants. PCBs have been sold under trade names such as Aroclor (Monsanto, USA, Canada, and UK), Phenoclor (Prodelec, France and Spain), Clophen (Bayer, Germany), Sovol and Sovtol (Orgsteklo, Orgsintez, former Soviet Union) and Kanechlor (Kanegafuchi, Japan). Typically,

\section{KARGER}

Fax +4161306 1234

E-Mail karger@karger.ch

www.karger.com
(C) 2008 S. Karger AG, Basel

$1464-1801 / 08 / 0153-0121 \$ 24.50 / 0$

Accessible online at:

www.karger.com $/ \mathrm{mmb}$
Dietmar H. Pieper

Biodegradation Research Group, Division of Microbiology

Helmholtz Centre for Infection Research, HZI, Inhoffenstrasse 7

DE-38124 Braunschweig (Germany)

Tel. +495316181 4200, Fax +495316181 4499, E-Mail dpi@helmholtz-hzi.de 
commercial PCB mixtures contain between 20 and 70 of the 209 theoretically possible congeners. It is estimated that more than 1.5 million tons of PCBs have been manufactured worldwide [Faroon et al., 2003], where a significant amount has been released into the environment and accumulated in soils and sediments [Nogales et al., 1999; Sericano et al., 1995]. The lipophilicity of PCBs contributes to their magnification in the food chain. Although adverse health effects were first recorded in the 1930s [Drinker et al., 1937], PCBs continued to be used for decades. Since then, PCBs have been shown to cause cancer [Mayes et al., 1998] and a number of serious effects on the immune, reproductive, nervous and endocrine system [Aoki, 2001; ATSDR, 2000; Faroon et al., 2001].

Bacteria play a fundamental role in the removal of waste chemical compounds from the environment. Bioremediation is a promising technology for the treatment of PCB-contaminated environments [Harkness et al., 1993; Pieper, 2005]. However, the process of bioremediation of PCBs is still not well understood and its microbial and molecular basis has to be further studied.

\section{Reductive Dehalogenation}

Although PCBs are highly stable environmental pollutants, their metabolism has been known for a few decades. Since the first report on bacterial metabolism of PCBs under anaerobic conditions in sediments of the Hudson River [Brown et al., 1987] numerous studies have since reported on the microbial dechlorination of PCBs in situ and in laboratory experiments with sediment slurries. Various dechlorination patterns in environmental and laboratory samples have been described. Typically, meta and/or para chlorines are removed to generate primarily ortho-substituted chlorobiphenyls, but ortho dechlorination of several PCB congeners has also been reported [Wiegel and $\mathrm{Wu}, 2000]$.

It has been known for more than one decade that chloroaromatics can function as an alternative electron acceptor in anaerobic respiration [Mohn and Tiedje, 1990]. Several anaerobic bacteria, such as the Dehalococcoides [Maymo-Gatell et al., 1999], the low GC Gram-positive bacteria Desulfitobacterium [Sanford et al., 1996], Dehalobacter [Holliger et al., 1998], the proteobacteria Desulfomonile [de Weerd and Suflita, 1990], Desulfuromonas [Krumholz, 1997], and Sulfospririllum [Boyle et al., 1999], have been identified as being able to reductively dehalogenate chlorinated phenols, benzoates, and trichloroethene and to couple this reaction to the synthesis of
ATP via a chemiosmotic mechanism [Mohn and Tiedje, 1991].

Organisms able to mediate the reductive dechlorination of PCBs have been difficult to identify by traditional isolation techniques. Using an approach that combined classical en richment protocols in a defined sediment-free medium with genetic screening of the microbial communities, two anaerobic PCB-dechlorinating microorganisms, $o-17$ and DF-1, both distantly related to Dehalococcoides ( $<90 \% 16 \mathrm{~S}$ rDNA sequence similarity, while sequence similarity among strains was very high, $>98 \%$ ) were identified as able to perform a reductive dehalogenation. While strain DF-1 specifically dechlorinates congeners with doubly flanked chlorines such as 2,3,4,5-tetrachlorobiphenyl $(2,3,4,5-\mathrm{CB})$ which is dechlorinated at the para position [Wu et al., 2002], the $o-17$ strain was capable of ortho dechlorination of 2,3,5,6-chlorobiphenyl to 2,3,5-trichloro- and 3,5-dichlorobiphenyl [Cutter et al., 2001] (fig. 1), a capability which is rarely observed in the environment. The $o-17$ strain culture was assayed with 26 PCB congeners and revealed that 8 PCBs could be dechlorinated [May et al., 2006], including singleflanked ortho PCB chlorines. However, double-flanked chlorines were preferentially dechlorinated, and the dechlorination of three congeners could be carried out by various sequential transfers. Nevertheless, the ability to dechlorinate more extensively chlorinated congeners was limited and some PCB congeners were shown to inhibit the process.

Dehalococcoides ethenogenes 195 was the first Dehalococcoides isolated based on its capability to dehalogenate tetrachloroethene to ethene [Maymo-Gatell et al., 1999]. The genome of strain 195 has been sequenced and 17 possible reductive dehalogenase genes were observed, suggesting a diverse dehalogenation ability [Seshadri et al., 2005]. However, only one dehalogenase encoded by tce $A$ and responsible for the dechlorination of trichloroethene, dichloroethene and vinylchloride has been isolated and characterized [Magnuson et al., 2000]. In fact, analysis of the capabilities of strain 195 revealed that this strain can dehalogenate different types of chlorinated aromatics in addition to its known chloroethene electron acceptors, including PCBs [Fennell et al., 2004]. Double-flanked chlorines could be dechlorinated by D. ethenogenes 195 (fig. 1), as in the case of strain DF-1. Dehalococcoides have also been implicated in the removal of double-flanked meta and para chlorines from 2,3,4,5-tetrachlorobiphenyl to form 2,3,5-trichloro- and 2,4,5-trichlorobiphenyl, respectively, in different enrichment cultures [Yan et al., 2006]. Fagervold et al. [2005] provided evidence for the 
<smiles>COc1cc(Cl)c(-c2ccccc2)c(Cl)c1</smiles>

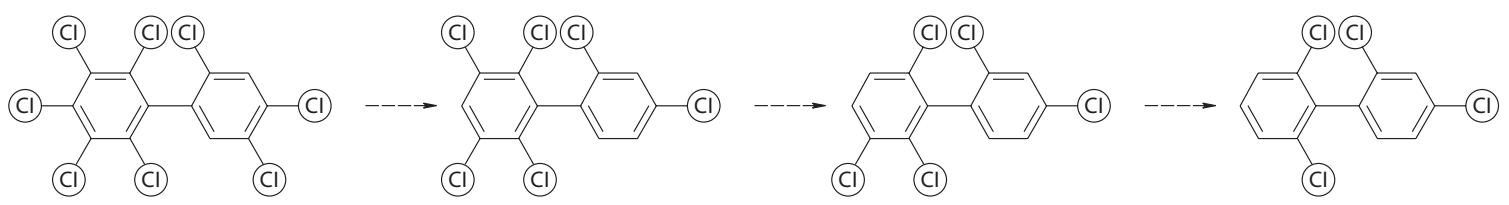

- Dechlorination of double-flanked chlorines of 2,3,4,5,6-pentachlorobiphenyl by Dehalococcoides ethenogenes strain 195

$\longrightarrow$ ortho dechlorination of 2,3,5,6-chlorobiphenyl by bacterial strain 0 -17

$\longrightarrow$ Dechlorination of $2,3,5,6,2^{\prime}, 4^{\prime}, 5^{\prime}$-heptachlorobiphenyl by an enrichment culture

Fig. 1. Bacterial reductive dehalogenation of selected polychlorinated biphenyls by Dehalococcoides and related bacteria and by an enrichment culture [Bedard et al., 2006; Cutter et al., 2001; Fennell et al., 2004].

involvement of two types of microorganisms belonging to the Dehalococcoides and $o-17 / \mathrm{DF}-1$ group, during the reductive dehalogenation of $2,2^{\prime}, 3,3^{\prime}, 4,6^{\prime}$-hexachlorobiphenyl to 2,2',4,6-tetrachlorobiphenyl. However, all the studies mentioned above analyzed the metabolism of only a few PCB congeners and do not reflect reductive dehalogenation processes observed in the environment. Only recently, a stable sediment-free culture showed to be able to dechlorinate Aroclor 1260 [Bedard et al., 2006]. Sixty-four PCB congeners were confirmed as substrates for this consortium, in which 47 congeners contained 6 or more chlorides. It was speculated that two or more Dehalococcoides strains with different sets of reductive dehalogenase genes act together to achieve the broad congener specificity observed (fig. 1). Considering that the isolated Dehalococcoides strains 195, FL2, BAV1, and CBDB1 contain 18, 14, 7 and 32 non-identical reductive dehalogenase genes, respectively [Holscher et al., 2004], there is a significant lack of knowledge on substrate specificity and distribution of such dehalogenases genes and thus their importance for bioremediation.

Bacterial Metabolism of Polychlorinated Biphenyls

\section{Aerobic Degradation}

Since the pioneering studies of Lunt and Evans [1970], Catelani et al. [1971] and Ahmed and Focht [1973a, b], several bacteria able to use biphenyl as a sole source of carbon and energy (predominantly Pseudomonas, Burkholderia, Comamonas, Cupriavidus, Sphingomonas, Acidovorax, Rhodococcus and Bacillus strains) have been isolated and their capability to transform PCB congeners has been evaluated. The degradation of biphenyl and transformation of PCBs is usually catalyzed by enzymes encoded by the so-called biphenyl upper (bph) pathway.

\section{The Biphenyl Upper (bph) Pathway}

A major interest for analyzing aerobic biphenyl degrading bacteria is because of their capability to transform PCB congeners. Based on the analysis of various biphenyl degrading isolates, it could be deduced that, in general, lower chlorinated congeners are more easily transformed compared to higher chlorinated congeners and that PCB congeners with chlorines only on one aro- 


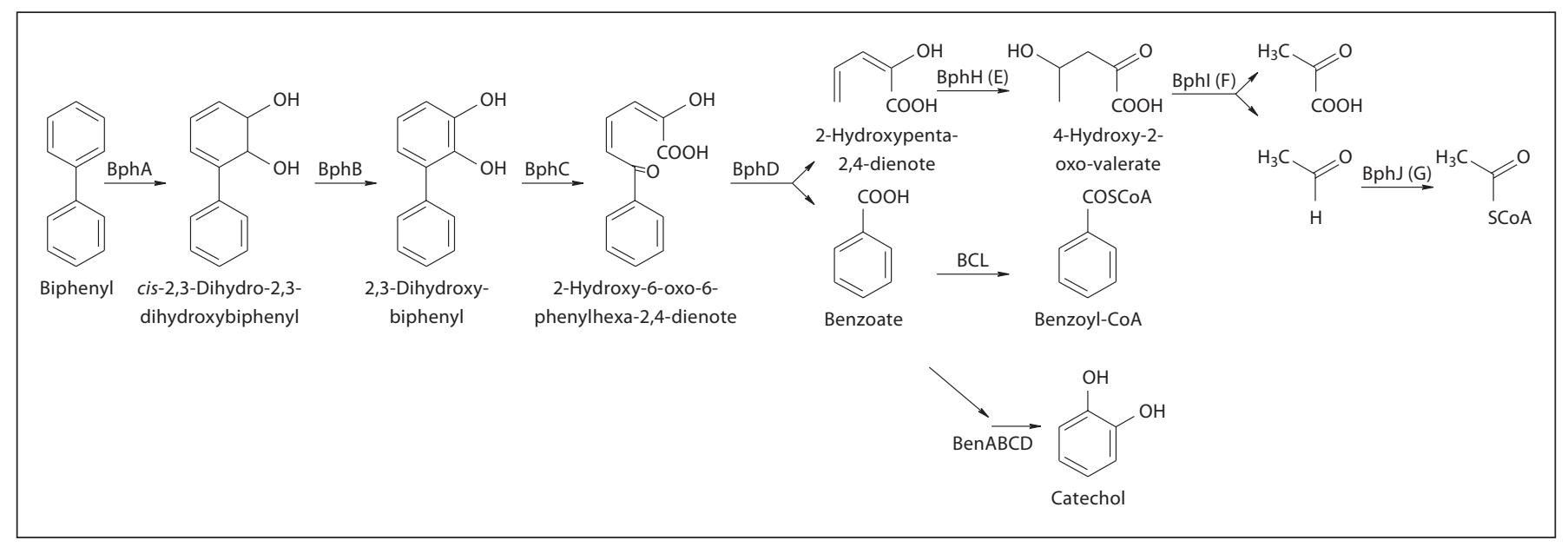

Fig. 2. Pathway for biphenyl degradation. $B$ phA = Biphenyl 2,3-dioxygenase; $B$ phB = cis-2,3-dihydro-2,3-dihydroxybiphenyl dehydrogenase; $\mathrm{BphC}=2,3$-dihydroxybiphenyl 1,2-dioxygenase; $\mathrm{BphD}=2$-hydroxy-6-phenyl6-oxohexa-2,4-dieneoate (HOPDA) hydrolase; $\mathrm{BphH}(\mathrm{E})$ = 2-hydroxypenta-2,4-dienoate hydratase; $\mathrm{BphI}(\mathrm{F})=$ acylating acetaldehyde dehydrogenase; $\mathrm{Bph}(\mathrm{G})=4$-hydroxy-2-oxovalerate aldolase; $\mathrm{BCL}=$ benzoate-CoA ligase; $\mathrm{Ben} \mathrm{ABCD}=$ benzoate 1,2-dioxygenase and benzoate dihydrodiol dehydrogenase.

matic ring are more easily degraded, when compared with those bearing chlorine substituents on both aromatic rings. However, each isolate exhibits a particular activity spectrum with regard to the type and extent of $\mathrm{PCB}$ congeners metabolized. Some strains have a narrow spectrum and others, notably Burkholderia xenovorans LB400 [Mondello, 1989], are able to transform a broad range of congeners [Bopp, 1986; Haddock et al., 1995; Mondello, 1989; Seeger et al., 1995a, b, 1997, 1999].

\section{Biphenyl 2,3-Dioxygenases}

The aerobic degradation of aromatic compounds is frequently initiated by Rieske non-heme iron oxygenases, which catalyze the incorporation of two oxygen atoms into the aromatic ring to form arene cis-diols [Gibson and Parales, 2000]. Rieske non-heme iron oxygenases are multicomponent enzyme complexes composed of a terminal oxygenase component (iron-sulfur protein [ISP]) and different electron transport proteins (a ferredoxin and a reductase or a combined ferredoxin-NADH-reductase) [Butler and Mason, 1997]. The catalytic iron-sulfur proteins are heteromultimers, comprising a large $(\alpha)$ and a small $(\beta)$ subunit, with the former containing a Riesketype [2Fe-2S] cluster, a mononuclear non-heme iron oxygen activation center, and a substrate-binding site [Butler and Mason, 1997; Furusawa et al., 2004] which is responsible for substrate specificity [Gibson and Parales, 2000]. Comparison of the amino acid sequences of the terminal oxygenase $\alpha$ subunits revealed that they form a family of diverse but evolutionarily related sequences, and distinct major lineages have been identified [Gibson and Parales, 2000]. Although none of the enzymes are strictly specific, a correlation between the subfamilies (e.g. toluene/biphenyl, naphthalene, benzoate, or phthalate subfamilies) and the oxidized substrates can be observed.

Biphenyl 2,3-dioxygenases (BphA) usually belong to the toluene/biphenyl branch of Rieske non-heme iron oxygenases [Gibson and Parales, 2000] where a ferredoxin and a ferredoxin reductase act as an electron transport system to transfer electrons from $\mathrm{NADH}$ to the terminal oxygenase. The biphenyl 2,3-dioxygenases are of crucial importance for the successful metabolism of PCBs (fig. 2). On the one hand, their dioxygenation regiospecificity determines the sites of attack by the subsequent metabolic pathway while, on the other hand, their specificity determine the spectrum of PCB congeners that can be transformed by an organism.

Studies on various biphenyl 2,3-dioxygenases have revealed considerable differences in their congener selectivity patterns, as well as their preference of the attacked ring [Kimura et al., 1997; McKay et al., 1997; Seeger et al., 1999]. The biphenyl pathway of strain LB400 oxidizes an unusually wide range of $\mathrm{PCB}$ congeners and $\mathrm{BphA}$ is able to dihydroxylate from mono-chlorobiphenyls to 2,3,4,5,2',5'-hexachlorobiphenyl [Haddock et al., 1995; Seeger et al., 1995a, b, 1997, 1999]. The following order of 
preference for dioxygenation has been observed: unsubstituted $>2$-chloro $>2,5$-dichloro $>2$,4-dichloro $\sim 3$ chloro $>4$-chloro $>2,3$-dichloro. Most primary catabolites that are dioxygenated by BphA from strain LB400 at ortho and meta carbons are further metabolized by the other enzymes of the upper pathway. In contrast, dioxygenation at meta and para positions results in channeling into a dead-end pathway. In addition to PCBs, BphA from strain LB400 is able to oxidize other substituted biphenyls, unsubstituted dibenzofuran and dibenzodioxin [Seeger et al., 2001]. Dehalogenation by BphA of orthochlorinated, -brominated and -fluorinated biphenyls has been observed [Haddock et al., 1995; Seeger et al., 1995b, 1997, 2001], in addition to denitration and dehydroxylation [Seeger et al., 2001]. Interestingly, BphA of LB400 is also able to transform different isoflavonoids [Seeger et al., 2003], compounds which are found in nature as secondary metabolites of plants. The isoflavonoid daidzein, a major phytoestrogen present in soy beans is dioxygenated by BphA, generating 7,2',4'-trihydroxyisoflavone after spontaneous dehydration. This has previously been used for chemical synthesis of substituted pterocarpans [Visser and Lane, 1987], plant metabolites which are suggested to be superior anti-tumor agents. The cis-2,3-dihydro-2,3-dihydroxybiphenyl dehydrogenase $(\mathrm{BphB}$, see below) from strain LB400 is able to rearomatize isoflavonoids dihydroxylated by BphA and the resulting products are assumed to have improved antioxidant properties [Arora et al., 1998].

Pollution by PCBs consists of mixtures of congeners and only a fraction of these can be transformed by BphAs. Therefore, for improved PCB catabolic pathways, recruitment or generation of biphenyl 2,3-dioxygenases with broadened and/or altered substrate ranges is required. Two main approaches have been employed to obtain novel BphA activities. One approach is to isolate naturally occurring $b p h A$ genes or gene segments from bacterial isolates [Camara et al., 2007] or from environmental DNA [Kahl and Hofer, 2003]. As an example, a hybrid BphA based on the LB400 enzyme but harboring the core segment of an oxygenase from Pseudomonas sp. strain B4-Magdeburg showed (depending on the congener considered) complementing or improved degradative properties [Camara et al., 2007]. The other approach is to generate altered enzymes through protein engineering and strategies of artificial evolution [Furukawa et al., 2004; Zielinski et al., 2006]. The construction of chimeric BphA derivatives, generated by the combination of gene segments of well known PCB degraders, enabled the identification of key domains of these oxygenases [Kimura et al., 1997; Kumamaru et al., 1998] and generated biphenyl 2,3-dioxygenases with improved capacities [Erickson and Mondello, 1993; Mondello et al., 1997; Suenaga et al., 1999, 2002]. A directed evolution approach using random mutagenesis to these specific segments allowed generating BphAs with increased catalytic turnover on PCBs, that were recalcitrant for the parental BphA from strain LB400 [Zielinski et al., 2006]. Recent studies have combined both approaches; the broad natural diversity and methods of artificial evolution by family shuffling of soil DNA encoding BphA segments to generate BphA variants with novel regioselectivities [Vezina et al., 2007].

\section{cis-2,3-Dihydro-2,3-Dihydroxybiphenyl}

\section{Dehydrogenases}

The second step in the metabolic pathway, the dehydrogenation of (chlorinated) cis-2,3-dihydro-2,3-dihydroxybiphenyls (biphenyl 2,3-dihydrodiol) producing (chlorinated) 2,3-dihydroxybiphenyl, is catalyzed by cis-2,3-dihydro-2,3-dihydroxybiphenyl dehydrogenases (BphB, fig. 2). cis-Dihydrodiol dehydrogenases are involved in various aromatic degradation pathways and exhibit common features such as an absolute requirement for $\mathrm{NAD}^{+}$. They are usually members of the family of short-chain alcohol dehydrogenases, showing a broad substrate specificity and able to transform several cis-dihydrodiol substrates [Jouanneau and Meyer, 2006; Patel and Gibson, 1974; Raschke et al., 1999; Rogers and Gibson, 1977]. As examples, NahB, involved in the degradation of naphthalene by $P$. putida G7, and BphB, involved in biphenyl degradation by $C$. testosteroni B-356, catalyze the transformation of biphenyl 2,3-dihydrodiol and naphthalene 1,2-dihydrodiol, although they only share $37 \%$ of sequence identity [Barriault et al., 1999]. In addition, both enzymes were able to catalyze the dehydrogenation of the $2,2^{\prime}, 5,5^{\prime}$-tetrachlorinated derivative of biphenyl 3,4-dihydrodiol. The broad substrate specificity of dihydrodiol dehydrogenases is further underlined by the fact that all biphenyl 2,3-dihydrodiols chlorinated at the non-oxidized ring, except for $2^{\prime}, 6^{\prime}$-substituted compounds, and various dihydrodiols chlorosubstituted at both aromatic rings were efficiently dehydrogenated by BphB of strain LB400 [Hülsmeyer et al., 1998].

\section{2,3-Dihydroxybiphenyl 1,2-Dioxygenases}

The ring-cleavage of aromatic intermediates possessing hydroxyl substituents on adjacent carbon atoms can be catalyzed by enzymes from one of two structurally and mechanistically distinct enzyme classes. While intradiol 
dioxygenases, which cleave the aromatic nucleus between the hydroxyl substituents (ortho-cleavage) use non-heme $\mathrm{Fe}(\mathrm{III})$, extradiol dioxygenases, that cleave the aromatic nucleus adjacent to the hydroxyl substituents (metacleavage) use non-heme Fe(II) in the reaction [Harayama and Rekik, 1989]. However, Mn(II)-dependent extradiol dioxygenases showing high sequence similarity to the $\mathrm{Fe}(\mathrm{II})$-dependent enzymes have been reported [Hatta et al., 2003]. Based on the sequence alignments, the extradiol group of dioxygenases has been divided in three families [Vaillancourt et al., 2003]. The type II extradiol dioxygenases include enzymes such as protocatechuate 4,5dioxygenase (Lig $\mathrm{AB}$ ) from Pseudomonas paucimobilis [Noda et al., 1990] which has two different types of subunits. The type III extradiol dioxygenases, including 1hydroxy-2-naphthoate dioxygenase from Nocardioides sp. strain KP7 [Iwabuchi and Harayama, 1998], belong to the cupin superfamily [Dunwell et al., 2001]. The type I extradiol dioxygenases belong to the vicinal oxygen chelate superfamily [Gerlt and Babbitt, 2001]. Both, one- and two-domain type I enzymes have been described, and their phylogenetic analysis indicates that these enzymes share a common one-domain ancestor [Eltis and Bolin, 1996]. Divergence has since resulted in several subfamilies. 2,3-Dihydroxybiphenyl 1,2-dioxygenases (BphC), and extradiol dioxygenases, which are involved in biphenyl degradation, usually belong to the I.3.A subfamily [Eltis and Bolin, 1996] and are specialized for transformation of 2,3-dihydroxybiphenyls (fig. 2).

The special interest on 2,3-dihydroxybiphenyl 1,2-dioxygenases is due to the fact that various studies indicate that activities of these enzymes limit the degradation of certain PCB congeners [Furukawa et al., 1979; Seeger et al., 1995a, 1997]. More detailed studies then revealed that those enzymes differ in substrate specificity, but seem to be generally capable of transforming various chlorosubstituted derivatives [Dai et al., 2002; Hein et al., 1998; McKay et al., 2003]. However, both 3,4-dihydroxybiphenyl as well as 2'-chlorosubstituted 2,3-dihydroxybiphenyls strongly inhibit 2,3-dihydroxybiphenyl 1,2-dioxygenases [Lloyd-Jones et al., 1995; McKay et al., 2003]. 2'-Chlorosubstituted 2,3-dihydroxybiphenyls promote suicide inactivation, which involves the release of superoxide radicals during catalysis and then the oxidation of the active site Fe(II) [Dai et al., 2002]. However, significant differences between different isoenzymes were observed [Fortin et al., 2005a] and specifically single domain extradiol dioxygenases have been shown to be adapted to the transformation of 2'-chlorosubstituted 2,3-dihydroxybiphenyls [McKay et al., 2003].

J Mol Microbiol Biotechnol 2008;15:121-138
A second feature of extradiol dioxygenases is their rapid inactivation during turnover of 3-chlorocatechol [Bartels et al., 1984]. 3-Chlorocatechol is a metabolic intermediate of 3-chlorobiphenyl degradation, which severely affect the PCB metabolism [Sondossi et al., 1992]. Efforts were directed towards the possible optimization of extradiol dioxygenases through directed evolution [Fortin et al., 2005b]. However, although variants with increased resistance to 3-chlorocatechol could be obtained [Ohnishi et al., 2004], this increase was only twofold and not comparable to natural variants of catechol 2,3-dioxygenases previously observed in chlorobenzene degrading Pseudomonas strains which are highly resistant to 3-chlorocatechol mediated inactivation [Göbel et al., 2004; Kaschabek et al., 1998].

\section{2-Hydroxy-6-Phenyl-6-Oxohexa-2,4-Dieneoate \\ (HOPDA) Hydrolases}

The fourth step in the $b p h$ pathway is catalyzed by 2-hydroxy-6-phenyl-6-oxohexa-2,4-dieneoate (HOPDA) hydrolase $\mathrm{BphD}$, which hydrolyzes HOPDA to yield 2-hydroxypenta-2,4-dienoate and benzoate (fig. 2). HOPDA hydrolases belong to the $\alpha / \beta$-hydrolase enzyme superfamily which include diverse hydrolytic enzymes sharing a similar structural fold [Ollis et al., 1992]. Most members of this superfamily are esterase and lipase enzymes that catalyze ester hydrolysis reactions by a serinehistidine-aspartate catalytic triad [Nardini and Dijkstra, 1999]. This superfamily also contains enzymes catalyzing a broad range of reactions, including a family of C-C hydrolase enzymes, and among them HOPDA hydrolases. Only limited information is available on the diversity of these hydrolases regarding their capability to transform chlorinated derivatives. Studies on Burkholderia xenovorans LB400 and Rhodococcus globerulus P6 BphDs, however have revealed that this enzyme may be a bottleneck for the metabolism of certain PCB congeners [Seah et al., 2000, 2001]. Although some differences in turnover were observed, both enzymes were similar in that HOPDAs bearing chlorine substituents at the phenyl moiety were efficiently transformed, whereas HOPDAs bearing chlorine substituents on the dienoate moiety were poor substrates and competitively inhibit BphD. Currently, more detailed mechanistic studies are being performed on these enzymes with the aim of use protein engineering approaches [Horsman et al., 2006; Li et al., 2006a, b].

\section{BphK Glutathione-S-Transferase}

$\mathrm{BphK}$ is a glutathione-S-transferase (GST) with an unclear function that occurs in some $b p h$ pathways [Bartels 
et al., 1999]. GSTs transform a wide range of electrophilic compounds in a reaction typically involving glutathione ( $\gamma$-L-Glu-L-Cys-Gly) conjugation [Armstrong, 1997]. Bacterial GSTs are integrated in a wide range of catabolic pathways, such as in the degradation of gentisate, homogentisate or pentachlorophenol. In the described pathway of Sphingobium chlorophenolicum, tetrachlorohydroquinone dehalogenase, which appears to have been recently recruited for pentachlorophenol degradation [Copley, 2000], catalyze the reductive dehalogenation of the substrate via trichlorohydroquinone to dichlorohydroquinone [Kiefer and Copley, 2002; Warner et al., 2005]. It was thus proposed that BphK could be involved in dechlorination of PCB catabolic intermediates [Hofer et al., 1994; Seeger et al., 1997]. BphK was shown not to be essential for degradation of biphenyl [Bartels et al., 1999]; however, Gilmartin et al. [2003] revealed that this enzyme can catalyze dehalogenation of 4-chlorobenzoate, the same product found from 4-chlorobiphenyl degradation by the enzymes BphA, BphB, BphC and BphD. Therefore, it was suggested that $\mathrm{BphK}$ was recruited to facilitate the degradation of PCBs. Recent studies revealed that BphK catalyzes the dehalogenation of 3-chloro-2-hydroxy-6-oxo6-phenyl-2,4-dieneoates (and some other chlorosubstituted derivatives), compounds that are produced by the cometabolism of PCBs by BphA, BphB and BphC [Fortin et al., 2006] and that inhibit BphD. In fact, 3-chloro2-hydroxy-6-oxo-6-phenyl-2,4-dieneoates were significantly better substrates for the enzyme compared to 4chlorobenzoate and it was proposed that BphK contributes to the superior PCB metabolizing activities of LB400 by decreasing the inhibition of $\mathrm{BphD}$ by chlorinated HOPDAs. Current efforts are being directed towards the mechanistic understanding of BphK catalysis [Tocheva et al., 2006].

\section{Lower Pathways for the Degradation of}

\section{2-Hydroxypenta-2,4-Dienoates and Benzoates}

The metabolism of (chloro)biphenyls by the biphenyl upper pathway results in the formation of (chlorinated) 2-hydroxypenta-2,4-dienoates and (chlorinated) benzoates (fig. 2). 2-Hydroxypenta-2,4-dienoate is transformed by 2-hydroxypenta-2,4-dienoate hydratase $(b p h H)$, an acylating acetaldehyde dehydrogenase (bphI) and 4-hydroxy-2-oxovalerate aldolase ( $b p h J)$ to acetyl-CoA, which then can enter the Krebs cycle. Thus, these enzymes should allow growth of bacterial strains on chlorinated biphenyls chlorinated only at one aromatic ring, which yield chlorinated benzoates as dead-end metabolites and unchlorinated 2-hydroxypenta-2,4-dienoate. Still, the transformation of chlorinated 2-hydroxypenta-2,4-dienoate should be elucidated.

The 2-hydroxypenta-2,4-dienoate transforming enzymes have been described from different PCB-degrading strains such as B. xenovorans LB400 and Rhodococcus sp. strain RHA1. The encoding genes are typically organized in a $b p h H J I$ (also termed $b p h E G F$ ) or bphHIJ cluster, respectively (fig. 2). However, while in LB400 and KF707 strains these genes are integrated in the upper pathway gene cluster [Hofer et al., 1994] (see below), in strain RHA1 (and others), they are separated from the archetype upper pathway gene cluster and encoded by eight (partially incomplete) clusters [Goncalves et al., 2006; McLeod et al., 2006], with only three of them being expressed during growth on biphenyl [Goncalves et al., 2006]. As homologous enzymes are integral parts of archetype catechol meta-cleavage pathways [Williams and Sayers, 1994], the remaining genes are probably involved in such central metabolic routes.

Besides 2-hydroxypenta-2,4-dienoates, benzoates are generated during $\mathrm{BphD}$ catalyzed hydrolysis of HOPDAs (fig. 2). Classically, benzoate is assumed to be mineralized via catechol and a 3-oxoadipate pathway [Harwood and Parales, 1996] (fig. 2). Recently, a new and unusual pathway for aerobic benzoate oxidation has been described in various bacteria including strain LB400 [Denef et al., 2004; Gescher et al., 2002; Zaar et al., 2001]. Benzoate is first transformed by benzoate-CoA ligase into benzoyl-CoA (fig. 2). Then, benzoyl-CoA is transformed by a benzoyl-CoA dioxygenase to 2,3-dihydroxydihydrobenzoyl-CoA followed by nonoxygenolytic cleavage of the aromatic ring and a $\beta$-oxidation-like pathway of the ring-cleavage product. This (box) pathway generates 3hydroxyadipyl-CoA and then 3-ketoadipyl-CoA, which is finally cleaved into succinyl-CoA and acetyl-CoA. Operon-like structures of box genes encoding both the initial ligase as well as the benzoyl-CoA pathway are present in LB400 strain in two copies on the major chromosome and on the mega plasmid [Chain et al., 2006]. However, this box pathway was not found in strain RHA1 [McLeod et al., 2006].

In addition to the box pathway, strain LB400 harbors an archetype benzoate degradation pathway via catechol and their respective functions were evaluated by proteomic and genomic studies [Denef et al., 2004, 2006]. It was established that benzoate, when supplied as a carbon source, was mainly metabolized via catechol, whereas benzoate generated from biphenyl was mainly metabolized via the box pathway. Thus, it was proposed that the box pathway is of advantage under oxygen limiting con- 
ditions, as it consumes less oxygen compared to the degradation via catechol due to the nonoxygenolytic ringcleavage [Denef et al., 2006; Gescher et al., 2005].

Although chlorobenzoates themselves are not very toxic to bacteria [Agulló et al., 2007; Martínez et al., 2007], negative effects of chlorobenzoate metabolism on chlorobiphenyl degradation have been reported [Havel and Reineke, 1992; Sondossi et al., 1992]. This is due to the channeling of chlorobenzoates via chlorocatechols into inappropriate pathways and includes the formation of toxic protoanemonin from 4-chlorocatechol by enzymes of the wide-spread 3-oxoadipate pathway [Blasco et al., 1995, 1997] and the suicide inactivation during the transformation of 3-chlorocatechol by extradiol dioxygenases [Bartels et al., 1984; Vaillancourt et al., 2002]. Bacteria have evolved various strategies to degrade chlorobenzoates. The degradation via chlorocatechol and the chlorocatechol ortho-cleavage pathway (clc pathway and others) are the most intensively studied [Dorn et al., 1974]. However, various alternative strategies have been described such as: (1) the hydrolytic dehalogenation of 4-chlorobenzoate to give 4 -hydroxybenzoate ( $f c b$ pathway) [Klages and Lingens, 1979], (2) the 4,5-dioxygenation of 3-chlorobenzoate and 3,4-dichlorobenzoate to form 5-chloroprotocatechuate [Nakatsu and Wyndham, 1993], (3) the degradation of 3-chlorocatechol by variants of the catechol meta-cleavage pathway [Mars et al., 1997], and (4) chlorocatechols by novel variants of chlorocatechol ortho-cleavage routes [Moiseeva et al., 2002; Nikodem et al., 2003] [for details on the degradation of chlorobenzoates, see Pieper, 2005]. To overcome restrictions due to poisoning caused by the production of toxic metabolites, the application of co-cultures and the construction of hybrid strains capable of mineralizing some lower chlorinated biphenyls by an appropriate combination of pathway segments have been considered [Brenner et al., 1994].

\section{Genomic Studies}

Burkholderia xenovorans strain LB400 and Rhodococcus sp. strain RHA1 are two model microorganisms which have been extensively studied due to their ability to metabolize a broad range of PCBs [Bopp, 1986; Seeger, et al., 1995a; Seto et al., 1995]. Both genomes have recently been sequenced [Chain et al., 2006; McLeod et al., 2006 ] with the rationale to better understand their overall physiology and to foster their applicability for bioremediation purposes. The LB400 genome has a size of 9.73 $\mathrm{Mb}$ and comprises two circular chromosomes (4.90 and $3.36 \mathrm{Mb}$, respectively) and a circular mega plasmid (1.47 $\mathrm{Mb})$. The RHA1 genome comprises $9.70 \mathrm{Mb}$ arranged on a linear chromosome $(7.80 \mathrm{Mb})$ and three linear plasmids (1.12, 044 and $0.33 \mathrm{Mb}$, respectively). Each of these genomes harbors $\sim 9,000$ coding sequences and both strains reside in soil and plant rhizosphere niches. These ecologically similar bacteria have evolved their large genomes by different means. More than $20 \%$ of the genome of strain LB400 was recently acquired via horizontal gene transfer (HGT). In contrast, strain RHA 1 evolved through ancient acquisition or gene duplication and acquired far fewer genes by recent HGT than LB400 [McLeod et al., 2006].

Strains LB400 and RHA1 both have the potential to degrade a wide range of aromatic compounds, and the genome sequences indicate unusually high metabolic versatilities. A broad range of xenobiotic and natural compounds are funneled by a large number of 'peripheral aromatic' pathways (20 and 26 , respectively) into fewer 'central aromatic' pathways ( 11 and 8 , respectively), significantly exceeding the degradative versatility of other sequenced aromatic degrading bacteria such as Pseudomonas putida KT2440 [Jimenez et al., 2002] or Aromatoleum EbN1 [Rabus et al., 2005].

The genes encoding enzymes of the biphenyl upper $b p h$ pathway are located in both strains on acquired and mobile genetic elements. In LB400 they are encoded by a genomic island on the mega plasmid, indicating that these genes were acquired via HGT. Genomic islands also provide other catabolic capacities such as the abilities to degrade 2-aminophenol or 3-chlorocatechol to strain LB400. In strain RHA1, the $b p h$ genes are, like 11 of the 26 peripheral aromatic pathways, located on the plasmids [McLeod et al., 2006].

\section{Toxicity and Stress}

The biodegradation performance of bacteria can be affected by the toxicity of the pollutants or metabolites derived from them [Blasco et al., 1997; Erb et al., 1997]. Due to their lipophilicity, PCBs are expected to accumulate in membranes [Sikkema et al., 1995] and, in fact PCB congeners, specifically lower chlorinated ones significantly reduce the viability of $E$. coli cells [Cámara et al., 2004]. Also, Park et al. [2000] indicated that PCBs decrease survival. Other studies suggested that PCB metabolites drastically affect the cell viability [Blasco et al., 1997; Cámara et al., 2004; Sondossi et al., 1992; Vaillancourt et al., 2002]. As described above, depending on the PCB congener and the $b p h$ enzymes harbored by a given organism, different pathway steps may constitute metabolic bottlenecks, resulting in the accumulation of the respective metabolites. Specifically, biphenyl dihydrodi- 
ols (formed by BphA) and dihydroxybiphenyls (formed by the subsequent action of $\mathrm{BphA}$ and $\mathrm{BphB}$; fig. 2) were reported to be highly toxic to both E. coli and LB400 cells, affecting the cell viability much more than PCBs [Cámara et al., 2004]. Hydroxylated PCB metabolites affected the DNA content of Comamonas testosteroni TK102 and inhibited cell separation [Hiraoka et al., 2002]. A recent study differentiated the effects of PCBs themselves and the possible metabolites on the performance of two fully sequenced potent PCB degraders, strains LB400 and RHA1 [Parnell et al., 2006]. Although PCBs were shown to partition to the cell fraction of cultures, no significant effects were observed regarding viability or growth rate in either strain under non PCB-degrading conditions. Strain LB400 was among the most potent PCB degraders exhibiting a high tolerance to PCB metabolites toxicity, while strain RHA1 showed to be highly sensitive.

The better performance of strain LB400 and the availability of the complete genome sequence make possible proteomic and transcriptomic studies in order to evaluate molecular defenses against PCB toxicity. During exposure of strain LB400 cells to 4-chlorobiphenyl, enlargement of the periplasmic space at the poles and electrondense granules in the cytoplasm have been described [Agulló et al., 2007]. These electron-dense granules correspond to polyphosphates [Chavez et al., 2004] which are accumulated by bacteria exposed to stress conditions [Kulaev and Kulakovskaya, 2000].

In addition, the induction of the molecular chaperones DnaK and GroEL by the presence of 4-chlorobiphenyl and biphenyl in LB400 [Agulló et al., 2007] suggests that the presence, and perhaps metabolism, of these compounds constitutes a stress. During growth on biphenyl, oxidative stress was evident by the induction of proteins such as alkyl hydroperoxide reductase AhpC [Agulló et al., 2007; Denef et al., 2005] which detoxify peroxides. LB400 cells grown on glucose and exposed to biphenyl showed increased levels of reactive oxygen species [Agulló et al., 2007], which may result from the action of oxygenases involved in metabolism [Bagneris et al., 2005].

Proteomic and transcriptomic studies could detect further responses of LB400 cells dealing with PCB and stress conditions. Both a quinoprotein methanol metabolic pathway and a putative chloroacetaldehyde dehydrogenase were observed to be highly expressed during (chloro)biphenyl metabolism [Denef et al., 2005; Parnell et al., 2006]. As in the case of chloroacetaldehyde dehydrogenase of Xanthobacter autotrophicus GJ10, that is essential to transform toxic metabolites during dichloroethane degradation [van der Ploeg et al., 1994], the pres-

Bacterial Metabolism of Polychlorinated Biphenyls ence of an homologue was suggested playing a similar role in the degradation of chlorinated aliphatic compounds originated from PCB degradation, and thus able to reduce the concentration of toxic PCB metabolites [Parnell et al., 2006].

\section{Archetype bph Gene Clusters}

Most of the information on biphenyl degradation and PCB metabolism comes from bacterial isolates, among them strains LB400 and RHA1, whose genomes have recently been elucidated. Strain LB400 [Mondello, 1989], similar to P. pseudoalcaligenes KF707 [Furukawa and Miyazaki, 1986], C. necator $\mathrm{H} 850$ [Bedard et al., 1987] and others [Bartels et al., 1999], harbor an operon comprising genes encoding biphenyl 2,3-dioxygenase (bphA1A2A3A4), cis-2,3-dihydro-2,3-dihydroxybiphenyl dehydrogenase (dihydrodiol dehydrogenase, $b p h B$ ), 2,3-dihydroxybiphenyl 1,2-dioxygenase $(b p h C)$ and 2-hydroxy6-oxo-6-phenylhexa-2,4-dienoate hydrolase (HOPDA hydrolase, $b p h D)$. The operon contains genes encoding a glutathione S-transferase ( $b p h K)$ and genes encoding enzymes involved in the transformation of 2-hydroxypenta-2,4-dienoate (which is released during hydrolysis of HOPDA to form benzoate) that are localized between $b p h C$ and $b p h D$ [Hofer et al., 1994] (fig. 3). Regulation of these clusters is assumed to be mediated by the orfo gene product, which belongs to the GntR family of transcriptional regulators [Beltrametti et al., 2001; Watanabe et al., 2000]. P. putida KF715 contains a bphABCD gene cluster [Hayase et al., 1990] (fig. 4) which was suggested to have evolved from a LB400-type gene cluster [Nishi et al., 2000].

In the strain LB400, the biphenyl catabolic genes are located on a genomic island on the mega plasmid [Chain et al., 2006]. The presence of $b p h$ genes on a genomic island implies that they have been acquired by HGT from other bacteria. The chromosomal $b p h$ genes in strains KF715 [Hayase et al., 1990; Lee et al., 1995] and in strain KF707 [Furukawa and Miyazaki, 1986] are able to move to other strains [Nishi et al., 2000]. The presence of $b p h$ genes on mobile genetic elements such as genomic islands, plasmids or (conjugative) transposons indicate that these genes are able to move between genomes, thus allowing adaptation of microbial communities to PCBs.

Another type of bph gene cluster (bphAaAbAcAdCB) was observed in Rhodococcus RHA1 [Masai et al., 1995] (fig. 3) and localized on the linear plasmid pRHL1 [Takeda et al., 2004]. This catabolic gene cluster is followed by $b p h S$ and $b p h T$ genes which encode a two-component signal transduction system composed of a BphT response 




Fig. 3. Genetic organization of the bph gene clusters of Burkholderia xenovorans LB400 [Chain et al., 2006; Hofer et al., 1994; Mondello, 1989], P. putida KF715 [Hayase et al., 1990; Nishi et al., 2000], Rhodococcus sp. strain M5 [Labbe et al., 1997; Peloquin and Greer, 1993], Acidovorax sp. strain KKS102 [Kikuchi et al., 1994;

regulator and a BpdS sensor kinase and promote transcriptional induction by a variety of aromatic compounds, including biphenyl, benzene, alkylbenzenes, and chlorinated benzenes [Takeda et al., 2004]. Importantly, this gene cluster is devoid of a $b p h D$ gene. A nearly identical gene cluster termed ipbA1A2A3A4CB involved in isopropylbenzene degradation has been localized on the linear plasmid pBD2 of R. erythropolis BD2 [Stecker et al., 2003]. This indicate that such gene clusters are involved in the degradation of differently substituted aromatics and that their designation as $b p h$ or ipb genes is rather historical than based on specificity. Moreover, their plasmid localization indicates that the $i p b$ and $b p h$ operons have been distributed among Gram-positive organisms via plasmid mediated HGT. Similar $b p h(i p b)$ gene clusters, which differ slightly in arrangement were observed in Rhodococcus strains M5 [Peloquin and Greer, 1993] and TA421 [Arai et al., 1998].

Another type of differently structured $b p h$ gene cluster was observed in Acidovorax sp. strain KKS102 [Kiku-
Kimbara et al., 1989; Ohtsubo et al., 2001], Bacillus sp. JF8 [Mukerjee-Dhar et al., 2005], Sphingobium yanoikuyae B1 [Kim and Zylstra, 1999; Yu et al., 2007], and of the bph and etb gene clusters of Rhodococcus sp. strain RHA1 [Kitagawa et al., 2001; Masai et al., 1995; McLeod et al., 2006]. chi et al., 1994] and Cupriavidus oxalaticus A5 [Merlin et al., 1997; Mouz et al., 1999; Springael et al., 1993] (bphSE GF(orf4)A1A2A3A4BCD(orf1)A4) (fig. 3). In these clusters, genes encoding for a 2-hydroxypenta-2,4-dieneoate hydratase, acetaldehyde dehydrogenase, and 4-hydroxy2 -oxovalerate aldolase (designated $b p h E G F$ ) are preceding genes encoding upper pathway enzymes. The gene encoding the reductase subunit of biphenyl dioxygenase

Fig. 4. Phylogenetic tree of the $\alpha$ subunits of selected Rieske nonheme iron oxygenases (a branches identified by Gibson and Parales [2000] are indicated) and of selected hydrolases involved in the degradation of meta-cleavage products formed during metabolism of aromatics ( $\mathbf{b}$ hydrolases typically described to be involved in the degradation of biphenyl and active with 2-hydroxy-6-phenyl-6-oxohexa-2,4-dieneoate (HOPDA) and hydrolases typically described to be involved in the degradation of catechols and active with 2-hydroxy-6-oxohepta-2,4-dieneoate (HOHDA) are indicated). 


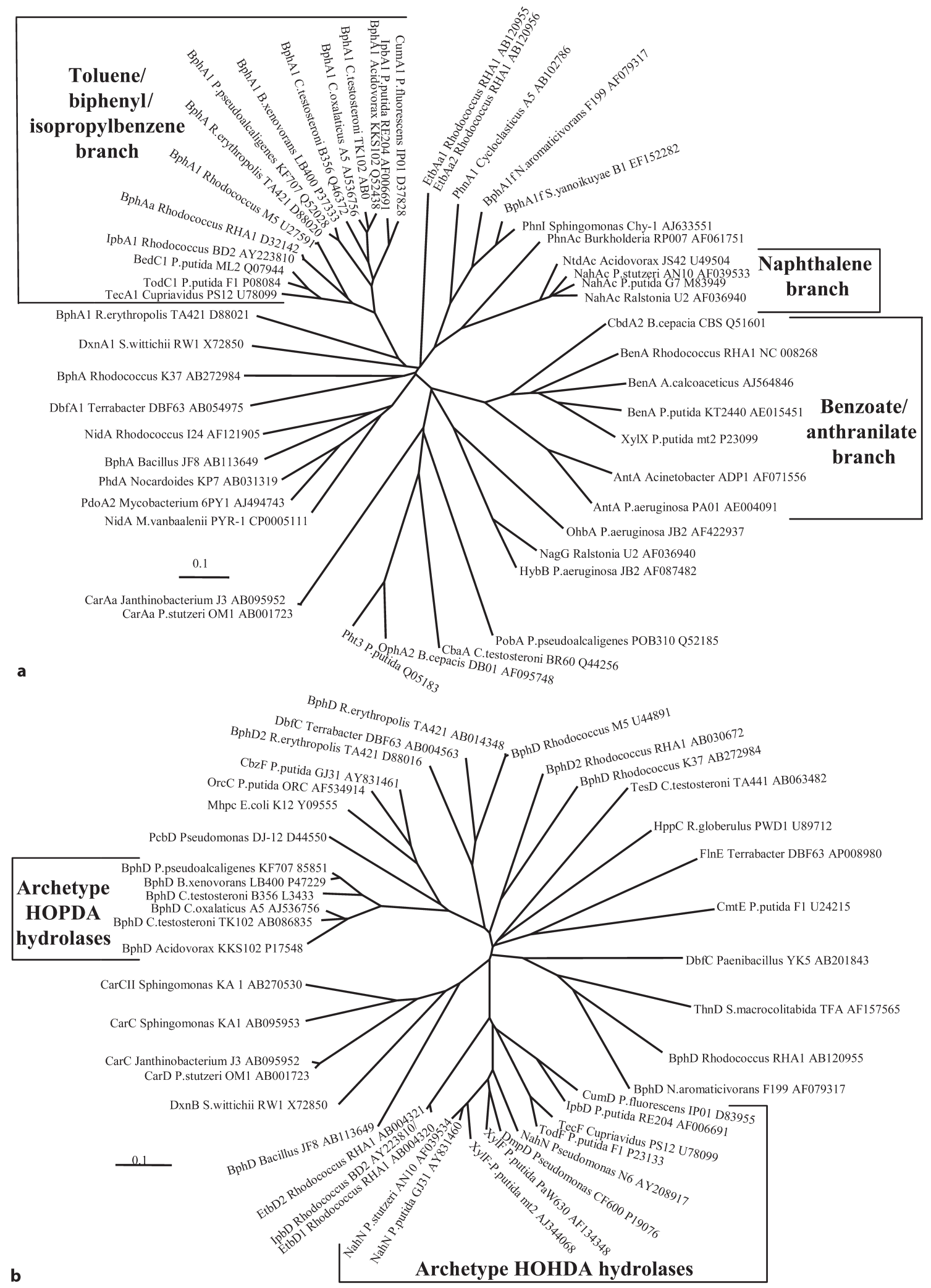

Bacterial Metabolism of Polychlorinated 
(bphA4) is localized at the end of the gene cluster. Regulation in strain KKS102 was shown to be dependent on the bphS gene product, which showed homology with the GntR family of transcriptional regulators [Mouz et al., 1999; Ohtsubo et al., 2001]. In Cupriavidus oxalaticus A5, the $b p h$ genes are located on $\mathrm{Tn} 4371$, a 55-kb mobile genomic island [Toussaint et al., 2003] which was found to integrate easily into the host chromosome at specific locations [Merlin et al., 1999]. Similar to other genomic islands, Tn4371 shows a mosaic structure of several building blocks including a tyrosine recombinase that is related to phage integrases [Merlin et al., 1999] and transfer most likely involves a site-specific excision/integration process.

\section{Metabolic Versatility}

The abundant information on PCB metabolism suggests that these archetype strains and catabolic gene clusters are those of major importance for PCB metabolism in the environment. However, enzymes homologous to those involved in biphenyl degradation could be found in pathways responsible for the degradation of other aromatic pollutants such as naphthalene, isopropylbenzene or benzene (fig. 4). Despite the evolutionary adaptation of enzymes for specific substrates, the enzymes of a particular pathway catalyze usually the transformation of a range of substrate analogues. On the other hand, the annotation of a certain gene/enzyme is usually based on a phenotype the host was selected for and does not necessarily reflect the detailed enzyme function. As an example, $b p h A a$ of strain RHA1 and ipbA1 of strain BD2 were initially described for their involvement in biphenyl and isopropylbenzene degradation, respectively [Dabrock et al., 1994; Masai et al., 1995]. However, their high sequence identity (99\%) and functional analyzes [Goncalves et al., 2006; Iwasaki et al., 2006; Kesseler et al., 1996] indicate that in both strains their function is to activate a diverse range of aromatic pollutants. In addition, other studies indicate that gene abbreviations given based on some 'archetype' isolates could be misleading. Studies on a benzene polluted site revealed an abundance of genes, which based on their function were termed isopropylbenzene dioxygenases, rather then those encoding the expected benzene/toluene dioxygenases [Witzig et al., 2006]. Evidence was given that the selected isopropylbenzene dioxygenases differed from previously described enzymes by a distinct active site architecture which prevent the transformation of even toluene.

It is well documented that various Rieske type nonheme iron oxygenases have the capability to transform biphenyl. As an example, chlorobenzene dioxygenase of Pseudomonas sp. P51 (belonging, like biphenyl dioxygenases, to the toluene/biphenyl branch of Rieske non-heme iron oxygenases) was shown to be capable of efficiently transforming monochlorinated biphenyls [Raschke et al., 2001]. On the other hand, enzymes outside of the toluene/ biphenyl branch of Rieske non-heme iron oxygenases were capable of transforming biphenyls, such as naphthalene dioxygenase of $P$. putida G7 (belonging to the naphthalene family of Rieske non-heme iron oxygenases) (fig. 4) [Barriault and Sylvestre, 1999], phenanthrene dioxygenase of Cycloclasticus sp. strain A5 [Kasai et al., 2003] and carbazole 1,9a-dioxygenase from Pseudomonas resinovorans CA10 [Nojiri et al., 1999]. It should be also noted that culture independent studies revealed the abundance of novel branches of Rieske-type non-heme iron oxygenases in contaminated sites. The importance and environmental function of these oxygenases still remains to be elucidated [Taylor and Janssen, 2005; Taylor et al., 2002; Witzig et al., 2006]. Overall, information on the sequence diversity of Rieske-type non-heme iron oxygenases has dramatically increased in recent years, also due to information available from genome projects, however, in most cases, a clear functional assignment could not be made.

Information is accumulating that Rieske-type nonheme iron oxygenases outside of the archetype toluene/ biphenyl branch are important for biphenyl degradation. The bph operon of Bacillus sp. JF8 harbors a novel bphRDA1A2BC cluster [Mukerjee-Dhar et al., 2005] (fig. 3) encoding enzymes only distantly related to enzymes previously described to be important for biphenyl degradation (fig. 4). BphA1 showed only $31 \%$ identity with BphA1 of LB 400 and is more closely related to naphthalene dioxygenases NidA from Rhodococcus sp. strain I24 [Larkin et al., 1999] or NidA from Mycobacterium vanbaalenii strain PYR-1 [Khan et al., 2001]. Also, the $\mathrm{Mn}$ (II)-dependent BphC and BphD (fig. 4) evidently belong to new subfamilies in the phylogeny of extradiol dioxygenases and hydrolases acting on extradiol cleavage products [Hatta et al., 2003; Mukerjee-Dhar et al., 2005].

The genetic analysis of biphenyl degrading Sphingomonas strains such as Sphingobium yanoikuyae B1 [Zylstra and Kim, 1997] or Novosphingobium aromaticivorans F199 [Romine et al., 1999] revealed a highly complex arrangement of catabolic genes differing immensely in sequence homology and gene order from those reported for other genera. The presence of various genes encoding oxygenase $\alpha$ subunits located in a large complex chromosomal gene cluster [Kim and Zylstra, 1999; Zylstra and 
Kim, 1997] significantly complicated the elucidation of their functions. Analysis revealed that a single ferredoxin and a single ferredoxin reductase, encoded by $b p h A 3$ and bphA4, respectively, are shared by multiple oxygenase systems [Bae and Kim, 2000]. Recently, the correct biphenyl dioxygenase genes (bphAlfA2f) were identified [Yu et al., 2007] which obviously receive electrons also from $\mathrm{BphA} 3$ and BphA4. In a phylogenetic analysis, BphA1f does not cluster with known BphAs, but is more related with the dioxygenase PhnI from Sphingomonas sp. strain CHY-1, which was shown to be able to oxidize at least 8 PAHs made of 2-5 aromatic rings [Demaneche et al., 2004; Jakoncic et al., 2007] and phenanthrene dioxygenase PhnA1 of Cycloclasticus sp. strain A5 [Kasai et al., 2003] (fig. 4).

These studies on Sphingomonas showed that different metabolic pathways are important, even within individual strains, for biphenyl degradation. However, this net of metabolic pathways is not exclusive of Sphingomonas sp. As shown in figure 4 , the $b p h$ cluster of Rhodococcus sp. strain RHA1 does not comprise a $b p h D$ gene, and such activity has to be recruited from elsewhere in the genome. In fact, three hydrolases were shown to be upregulated during growth of RHA1 on biphenyl [Goncalves et al., 2006] with one of them, termed BphD previously shown to be capable to attack HOPDA [Yamada et al., 1998]. Notably, the $b p h D$ gene is located in a gene cluster termed etbAa1Ab2CbphDE2F2 (fig. 3) in a gene region comprising an additional gene cluster (etbAa2Ab2AcD2) and various other genes involved in ethylbenzene/biphenyl degradation [bphF4, bphG4, bphE4, bphT2, bphS2, etbAd and $b p h B 2$ an 'astonishing' mix of genes being involved in ethylbenzene (etb) and biphenyl degradation $(b p h)]$ (fig. 3). Although the etbA1 encoded oxygenase $\alpha$ subunit is only distantly related to previously characterized BphA1 proteins (fig. 4), it is more active on highly chlorinated congeners than the $b p h A a$ encoded one [Iwasaki et al., 2006] and obviously appropriate for both biphenyl and ethylbenzene transformation. Furthermore, other subfamilies of biphenyl oxygenase $\alpha$ subunits are currently been discovered (e.g. BphA1 of Rhodococcus sp. strain K37, fig. 4), evidencing that diversity of oxygenases involved in biphenyl degradation is underestimated.

We can conclude that the metabolism of biphenyl and PCBs should not be regarded as a simple linear pathway. In fact, the different catabolic gene modules interact in a complex metabolic network. This is also supported by the observation that $P$. putida strain CE2010 mineralizes biphenyl by a mosaic of tod (toluene) and cmt (cumate) pathways in the absence of an 'authentic' biphenyl path- way [Ohta et al., 2001]. As previously reported, toluene dioxygenase (TodC1C2BA), toluene dihydrodiol dehydrogenase (TodD) and the meta-cleavage enzyme TodE have a significant cross-reactivity with biphenyl or metabolites produced during biphenyl degradation [Furukawa et al., 1993], whereas TodF 2-hydroxy-6-oxohepta2,4-dienoate hydrolase cannot cope with HOPDA. Recruitment of a hydrolase active with HOPDA, such as in RHA1 then allows CE21010 to mineralize biphenyl. As shown in figure 4, various different types of hydrolases active with HOPDA have been described and the recruitment of any of those can, at least in theory, complement $b p h$ gene modules. The same holds for extradiol dioxygenases, and especially in Rhodococcus, where the presence of multiple extradiol dioxygenase encoding genes has been reported [McLeod et al., 2006; Taguchi et al., 2004]. The metabolic versatility of catabolic enzymes and pathways is an indication of the ongoing evolution of bacterial metabolism, thus endowing environmental microbes with the capabilities to deal with a broad range of pollutants.

\section{Acknowledgements}

The authors would like to acknowledge financial support by grant EU ICA4-CT2002-10011. M.S. gratefully acknowledges support from the grants FONDECYT (1070507, 1020221 and 7020221), USM (130522), MILENIO P04/007-F (MIDEPLAN) and CONICYT-BMBF. D.P. gratefully acknowledges support from the grant EU GOCE 003998 (BIOTOOL).

\footnotetext{
References Agulló L, Cámara B, Martínez P, Latorre V, Seeger M: Response to (chloro)biphenyls of the polychlorobiphenyl-degrader Burkholderia xenovorans LB400 involves stress proteins also induced by heat shock and oxidative stress. FEMS Microbiol Lett 2007;267: 167-175.

-Ahmed M, Focht DD: Degradation of polychlorinated biphenyls by two species of Achromobacter. Can J Microbiol 1973a;19:47-52.

Ahmed M, Focht DD: Oxidation of polychlorinated biphenyls by Achromobacter pCB. Bull Environ Contam Toxicol 1973b;10:70-72.

Aoki Y: Polychlorinated biphenyls, polychlorinated dibenzo-p-dioxins, and polychlorinated dibenzofurans as endocrine disrupters-what we havelearned from Yusho disease. Environ Res 2001;86:2-11.

-Arai H, Kosono S, Taguchi K, Maeda M, Song E, Fuji F, Chung SY, Kudo T: Two sets of biphenyl and PCB degradation genes on a linear plasmid in Rhodococcus erythropolis TA421. J Ferm Bioeng 1998;86:595-599.
} 
Armstrong RN: Structure, catalytic mechanism, and evolution of the glutathione transferases. Chem Res Toxicol 1997;10:2-18.

-Arora A, Nair MG, Strasburg GM: Antioxidant activities of isoflavones and their biological metabolites in a liposomal system. Arch Biochem Biophys 1998;356:133-141.

ATSDR: Toxicological Profile for Polychlorinated Biphenyls (PCBs). Atlanta, Agency for Toxic Substances and Disease Registry, US Department of Health and Human Services, Public Health Service, 2000.

Bae M, Kim E: Association of a common reductase with multiple aromatic terminal dioxygenases in Sphingomonas yanoikuyae strain B1. J Microbiol 2000;38:40-43.

Bagneris C, Cammack R, Mason JR: Subtle difference between benzene and toluene dioxygenases of Pseudomonas putida. Appl Environ Microbiol 2005;71:1570-1580.

- Barriault D, Sylvestre M: Catalytic activity of Pseudomonas putida strain G7 naphthalene 1,2-dioxygenase on biphenyl. Int Biodeterio Biodegrad 1999;44:33-37.

- Barriault D, Vedadi M, Powlowski J, Sylvestre M: cis-2,3-dihydro-2,3-dihydroxybiphenyl dehydrogenase and cis-1,2-dihydro-1,2-dihydroxynaphathalene dehydrogenase catalyze dehydrogenation of the same range of substrates. Biochem Biophys Res Commun 1999;260:181-187.

- Bartels F, Backhaus S, Moore ERB, Timmis KN, Hofer B: Occurrence and expression of glutathione-S-transferase-encoding $b p h K$ genes in Burkholderia sp. strain LB400 and other biphenyl-utilizing bacteria. Microbiology 1999; 145:2821-2834.

Bartels I, Knackmuss H-J, Reineke W: Suicide inactivation of catechol 2,3-dioxygenase from Pseudomonas putida mt-2 by 3-halocatechols. Appl Environ Microbiol 1984;47:500505.

Bedard DL, Bailey JJ, Reiss BL, Jerzak GV: Development and characterization of stable sediment-free anaerobic bacterial enrichment cultures that dechlorinate aroclor 1260. Appl Environ Microbiol 2006;72:2460-2470.

Bedard DL, Haberl ML, May RJ, Brennan MJ: Evidence for novel mechanisms of polychlorinated biphenyl metabolism in Alcaligenes eutrophus H850. Appl Environ Microbiol 1987;53:1103-1112.

- Beltrametti F, Reniero D, Backhaus S, Hofer B: Analysis of transcription of the $b p h$ locus of Burkholderia sp strain LB400 and evidence that the ORF0 gene product acts as a regulator of the promoter. Microbiology 2001;147: 2169-2182.

-Blasco R, Mallavarapu M, Wittich RM, Timmis KN, Pieper DH: Evidence that formation of protoanemonin from metabolites of 4-chlorobiphenyl degradation negatively affects the survival of 4-chlorobiphenyl-cometabolizing microorganisms. Appl Environ Microbiol 1997;63:427-434.
Blasco R, Wittich R-M, Mallavarapu M, Timmis KN, Pieper DH: From xenobiotic to antibiotic. Formation of protoanemonin from 4chlorocatechol by enzymes of the 3-oxoadipate pathway. J Biol Chem 1995;270: 29229-29235.

Bopp L: Degradation of highly chlorinated PCBs by Pseudomonas strain LB400. I Ind Microbiol 1986;1:23-29.

Boyle AW, Phelps CD, Young LY: Isolation from estuarine sediments of a Desulfovibrio strain which can grow on lactate coupled to the reductive dehalogenation of 2,4,6-tribromophenol. Appl Environ Microbiol 1999;65: 1133-1140.

-Brenner V, Arensdorf JJ, Focht DD: Genetic construction of PCB degraders. Biodegradation 1994;5:359-377.

- Brown JF Jr, Bedard DL, Brennan MJ, Carnahan JC, Feng H, Wagner RE: Polychlorinated biphenyl dechlorination in aquatic sediments. Science 1987;236:709-712.

Butler CS, Mason J: Structure-function analysis of the bacterial aromatic ring-hydroxylating dioxygenases. Adv Microb Physiol 1997;38: 47-84.

Cámara B, Seeger M, González M, StandfussGabisch C, Kahl S, Hofer B: Generation of a hybrid dioxygenase showing improved oxidation of polychlorobiphenyls by a widely applicable approach. Appl Environ Microbiol 2007;73:2682-2689.

Catelani D, Sorlini C, Treccani V: The metabolism of biphenyl by Pseudomonas putida. Experientia 1971;27:1173-1174.

Chain PS, Denef VJ, Konstantinidis KT, Vergez LM, Agulló L, Reyes VL, Hauser L, Córdova M, Gómez L, Gónzalez M, Land M, Lao V, Larimer F, LiPuma JJ, Mahenthiralingam E, Malfatti SA, Marx CJ, Parnell JJ, Ramette A, Richardson P, Seeger M, Smith D, Spilker T, Sul WJ, Tsoi TV, Ulrich LE, Zhulin IB, Tiedje JM: Burkholderia xenovorans LB400 harbors a multi-replicon, 9.73-Mbp genome shaped for versatility. Proc Natl Acad Sci USA 2006;103:15280-15287.

Chavez FP, Lünsdorf H, Jerez CA: Growth of polychlorinated-biphenyl-degrading bacteria in the presence of biphenyl and chlorobiphenyls generates oxidative stress and massive accumulation of inorganic polyphosphate. Appl Environ Microbiol 2004;70: 3064-3072.

Cho OY, Choi KY, Zylstra GJ, Kim YS, Kim SK, Lee JH, Sohn HY, Kwon GS, Kim YM, Kim E: Catabolic role of a three-component salicylate oxygenase from Sphingomonas yanoikuyae $\mathrm{B} 1$ in polycyclic aromatic hydrocarbon degradation. Biochem Biophys Res Commun 2005;327:656-662.

Copley SD: Evolution of a metabolic pathway for degradation of a toxic xenobiotic: the patchwork approach. Trends Biochem Sci 2000;25: 261-265.
Cutter LA, Watts JEM, Sowers KR, May HD: Identification of a microorganism that links its growth to the reductive dechlorination of 2,3,5,6-chlorobiphenyl. Environ Microbiol 2001;3:699-709.

-Cámara B, Herrera C, González M, Couve E, Hofer B, Seeger M: From PCBs to highly toxic metabolites by the biphenyl pathway. Environ Microbiol 2004;6:842-850.

Dabrock B, Keßeler M, Averhoff B, Gottschalk G: Identification and characterization of a transmissible linear plasmid from Rhodococcus erythropolis $\mathrm{BD} 2$ that encodes isopropylbenzene and trichloroethene catabolism. Appl Environ Microbiol 1994;60:853-860.

-Dai S, Vaillancourt F, Maaroufi H, Drouin N, Neau D, Snieckus V, Bolin J, Eltis L: Identification and analysis of a bottleneck in PCB biodegradation. Nat Struct Biol 2002;9:934939.

de Weerd KA, Suflita JM: Anaerobic aryl reductive dehalogenation of halobenzoates by cell extracts of 'Desulfomonile tiedjei'. Appl Environ Microbiol 1990;56:2999-3005.

- Demaneche S, Meyer C, Micoud J, Louwagie M, Willison JC, Jouanneau Y: Identification and functional analysis of two aromatic-ring-hydroxylating dioxygenases from a Sphingomonas strain that degrades various polycyclic aromatic hydrocarbons. Appl Environ Microbiol 2004;70:6714-6725.

Denef VJ, Klappenbach JA, Patrauchan MA, Florizone C, Rodrigues JL, Tsoi TV, Verstraete W, Eltis LD, Tiedje JM: Genetic and genomic insights into the role of benzoate-catabolic pathway redundancy in Burkholderia xenovorans LB400. Appl Environ Microbiol 2006; 72:585-595.

Denef VJ, Park J, Tsoi TV, Rouillard JM, Zhang H, Wibbenmeyer JA, Verstraete W, Gulari E, Hashsham SA, Tiedje JM: Biphenyl and benzoate metabolism in a genomic context: outlining genome-wide metabolic networks in Burkholderia xenovorans LB400. Appl Environ Microbiol 2004;70:4961-4970.

- Denef VJ, Patrauchan MA, Florizone C, Park J, Tsoi TV, Verstraete W, Tiedje JM, Eltis LD: Growth substrate- and phase-specific expression of biphenyl, benzoate, and C1 metabolic pathways in Burkholderia xenovorans LB400. J Bacteriol 2005;187:7996-8005.

Dorn E, Hellwig M, Reineke W, Knackmuss H-J: Isolation and characterization of a 3-chlorobenzoate degrading pseudomonad. Arch Microbiol 1974;99:61-70.

Drinker CK, Warren MF, Bennet GA: The problem of possible systemic effects from certain chlorinated hydrocarbons. J Ind Hyg Toxicol 1937;19:283-311.

Dunwell JM, Culham A, Carter C, Sos-Aguirre C, PW G: Evolution of functional diversity in the cupin superfamily. Trends Biochem Sci 2001;26:740-746.

Eltis LD, Bolin JT: Evolutionary relationships among extradiol dioxygenases. J Bacteriol 1996;178:5930-5937. 
Erb RW, Eichner CA, Wagner-Döbler I, Timmis $\mathrm{KN}$ : Bioprotection of microbial communities from toxic phenol mixtures by a genetically designed pseudomonad. Nat Biotechnol 1997;15:378-382.

-Erickson BD, Mondello FJ: Enhanced biodegradation of polychlorinated biphenyls after site-directed mutagenesis of a biphenyl dioxygenase gene. Appl Environ Microbiol 1993;59:3858-3862.

Fagervold SK, Watts JE, May HD, Sowers KR: Sequential reductive dechlorination of metachlorinated polychlorinated biphenyl congeners in sediment microcosms by two different Chloroflexi phylotypes. Appl Environ Microbiol 2005;71:8085-8090.

Faroon O, Jones D, de Rosa C: Effects of polychlorinated biphenyls on the nervous system. Toxicol Ind Health 2001;16:305-333.

Faroon O, Keith L, Smith-Simon C, De Rosa C: Polychlorinated Biphenyls. Human Health Aspects. Concise International Chemical Assessment Document 55. Geneva, World Health Organization, 2003.

- Fennell DE, Nijenhuis I, Wilson SF, Zinder SH, Haggblom MM: Dehalococcoides ethenogenes strain 195 reductively dechlorinates diverse chlorinated aromatic pollutants. Environ Sci Technol 2004;38:2075-2081.

Fortin PD, Horsman G, Yang H, Eltis LD: A glutathione S-transferase catalyzes the dehalogenation of inhibitory metabolites of polychlorinated biphenyls. J Bacteriol 2006; 188: 4424-4430.

-Fortin PD, Lo ATF, Haro MA, Kaschabek SR, Reineke W, Eltis LD: Evolutionarily divergent extradiol dioxygenases possess higher specificities for polychlorinated biphenyl metabolites. J Bacteriol 2005a;187:415-421.

-Fortin PD, MacPherson I, Neau DB, Bolin JT, Eltis LD: Directed evolution of a ring-cleaving dioxygenase for polychlorinated biphenyl degradation. J Biol Chem 2005b;280: 42307-42314.

-Furukawa K, Hirose J, Suyama A, Zaiki T, Hayashida S: Gene components responsible for discrete substrate specifity in the metabolism of biphenyl (bph operon) and toluene (tod operon). J Bacteriol 1993;175:52245232.

- Furukawa K, Miyazaki T: Cloning of a gene cluster encoding biphenyl and chlorobiphenyl degradation in Pseudomonas pseudoalcaligenes. J Bacteriol 1986;166:392-398.

- Furusawa Y, Nagarajan V, Tanokura M, Masai E, Fukuda M, Senda T: Crystal structure of the terminal oxygenase component of biphenyl dioxygenase derived from Rhodococcus $\mathrm{sp}$ strain RHA1. J Mol Biol 2004;342:10411052.

-Furukawa K, Suenaga H, Goto M: Biphenyl dioxygenases: functional versatilities and directed evolution. J Bacteriol 2004;186:51895196.
Furukawa K, Tomizuka N, Kamibayashi A: Effect of chlorine substitution on the bacterial metabolism of various polychlorinated biphenyls. Appl Environ Microbiol 1979;38: 301-310.

-Gerlt JA, Babbitt PC: Divergent evolution of enzymatic function: Mechanistically diverse superfamilies and functionally distinct suprafamilies. Annu Rev Biochem 2001;70: 209-246.

Gescher J, Eisenreich W, Worth J, Bacher A, Fuchs G: Aerobic benzoyl-CoA catabolic pathway in Azoarcus evansii: studies on the non-oxygenolytic ring cleavage enzyme. Mol Microbiol 2005;56:1586-1600.

- Gescher J, Zaar A, Mohamed M, Schagger H, Fuchs G: Genes coding for a new pathway of aerobic benzoate metabolism in Azoarcus evansii. J Bacteriol 2002;184:6301-6315.

Gibson DT, Parales RE: Aromatic hydrocarbon dioxygenases in environmental biotechnology. Curr Opin Biotechnol 2000;11:236243.

- Gilmartin N, Ryan D, Sherlock O, Dowling DN: BphK shows dechlorination activity against 4-chlorobenzoate, an end-product of $b p h$ promoted degradation of PCBs. FEMS Microbiol Lett 2003;222:251-255.

-Goncalves E, Hara H, Miyazawa D, Davies J, Eltis LD, Mohn WW: Transcriptomic assessment of isoenzymes in the biphenyl pathway of Rhodococcus sp. strain RHA1. Appl Environ Microbiol 2006;72:6183-6193.

-Göbel M, Kranz OH, Kaschabek SR, Schmidt E, Pieper DH, Reineke W: Microorganisms degrading chlorobenzene via a meta-cleavage pathway harbor highly similar chlorocatechol 2,3-dioxygenase-encoding gene clusters. Arch Microbiol 2004;182:147-156.

Haddock JD, Horton JR, Gibson DT: Dihydroxylation and dechlorination of chlorinated biphenyls by purified biphenyl 2,3-dioxygenase from Pseudomonas sp. strain LB400. J Bacteriol 1995;177:20-26.

Harayama S, Rekik M: Bacterial aromatic ringcleavage enzymes are classified into two different gene families. J Biol Chem 1989;264: 15328-15333.

Harkness MR, McDermott JB, Abramowicz DA, Salvo JJ, Flanagan WP, Stephens ML, Mondello FJ, May RJ, Lobos JH, Carroll KM, Brennan MJ, Bracco AA, Fish KM, Warner GL, Wilson PR, Dietrich DK, Lin DT, Morgan $\mathrm{CB}$, Gately WL: In situ stimulation of aerobic PCB biodegradation in Hudson River sediments. Science 1993;259:503-507.

Harwood CS, Parales RE: The beta-ketoadipate pathway and the biology of self-identity. Annu Rev Microbiol 1996;50:553-590.

-Hatta T, Mukerjee-Dhar G, Damborsky J, Kiyohara $\mathrm{H}$, Kimbara $\mathrm{K}$ : Characterization of a novel thermostable $\mathrm{Mn}(\mathrm{II})$-dependent 2,3dihydroxybiphenyl 1,2-dioxygenase from a polychlorinated biphenyl- and naphthalenedegrading Bacillus sp JF8. J Biol Chem 2003; 278:21483-21492.
Havel J, Reineke W: Degradation of Aroclor 1221 and survival of strains in soil microcosms. Appl Microbiol Biotechnol 1992;38:129134

Hayase N, Taira K, Furukawa K: Pseudomonas putida KF715 bphABCD operon encoding biphenyl and polychlorinated biphenyl degradation: cloning analysis, and expression in soil bacteria. J Bacteriol 1990;172:11601164.

Hein P, Powlowski J, Barriault D, Hurtubise Y, Ahmad D, Sylvestre M: Biphenyl-associated meta-cleavage dioxygenases from Comamonas testosteroni B-356. Can J Microbiol 1998; 44:42-49.

Hiraoka Y, Yamada T, Tone K, Futaesaku Y, Kimbara K: Flow cytometry analysis of changes in the DNA content of the polychlorinated biphenyl degrader Comamonas testosteroni TK102: effect of metabolites on cell-cell separation. Appl Environ Microbiol 2002;68:5104-5112.

-Hofer B, Backhaus S, Timmis KN: The biphenyl/ polychlorinated biphenyl-degradation locus $(b p h)$ of Pseudomonas sp. LB400 encodes four additional metabolic enzymes. Gene 1994; 144:9-16.

-Holliger C, Hahn D, Harmsen H, Ludwig W, Schumacher W, Tindall B, Vazquez F, Weiss $\mathrm{N}$, Zehnder AJB: Dehalobacter restrictus gen. nov. and sp. nov., a strictly anaerobic bacterium that reductively dechlorinates tetraand trichloroethene in an anaerobic respiration. Arch Microbiol 1998;169:313-321.

-Holscher T, Krajmalnik-Brown R, Ritalahti KM, Von Wintzingerode F, Gorisch H, Loffler FE, Adrian L: Multiple nonidentical reductivedehalogenase-homologous genes are common in Dehalococcoides. Appl Environ Microbiol 2004;70:5290-5297.

-Horsman G, Ke J, Dai S, Seah SYK, Bolin JT, Eltis LD: Kinetic and structural insight into the mechanism of BphD, a C-C bond hydrolase from the biphenyl degradation pathway. Biochemistry 2006;45:11071-11086.

Hülsmeyer M, Hecht HJ, Niefind K, Hofer B, Eltis LD, Timmis KN, Schomburg D: Crystal structure of cis-biphenyl-2,3-dihydrodiol2,3-dehydrogenase from a PCB degrader at 2.0 A resolution. Protein Sci 1998;7:12861293.

Iwabuchi T, Harayama S: Biochemical and molecular characterization of 1-hydroxy-2naphthoate dioxygenase from Nocardioides sp. KP7. J Biol Chem 1998;273:8332-8336.

- Iwasaki T, Miyauchi K, Masai E, Fukuda M: Multiple-subunit genes of the aromatic-ringhydroxylating dioxygenase play an active role in biphenyl and polychlorinated biphenyl degradation in Rhodococcus sp. strain RHA1. Appl Environ Microbiol 2006;72: 5396-5402.

Jakoncic J, Jouanneau Y, Meyer C, Stojanoff V: The catalytic pocket of the ring-hydroxylating dioxygenase from Sphingomonas CHY-1. Biochem Biophys Res Commun 2007;352: 861-866. 
-Jimenez JI, Minambres B, Garcia JL, Diaz E: Genomic analysis of the aromatic catabolic pathwaysfrom Pseudomonasputida KT2440. Environ Microbiol 2002;4:824-841.

-Jouanneau Y, Meyer C: Purification and characterization of an arene cis-dihydrodiol dehydrogenase endowed with broad substrate specificity toward polycyclic aromatic hydrocarbon dihydrodiols. Appl Environ Microbiol 2006;72:4726-4734.

Kahl S, Hofer B: A genetic system for the rapid isolation of aromatic-ring-hydroxylating dioxygenase activities. Microbiology 2003; 149:1475-1481.

Kasai Y, Shindo K, Harayama S, Misawa N: Molecular characterization and substrate preference of a polycyclic aromatic hydrocarbon dioxygenase from Cycloclasticus sp. strain A5. Appl Environ Microbiol 2003;69:66886697.

Kaschabek SR, Kasberg T, Müller D, Mars AE, Janssen DB, Reineke W: Degradation of chloroaromatics: Purification and characterization of a novel type of chlorocatechol 2,3-dioxygenase of Pseudomonas putida GJ31. J Bacteriol 1998;180:296-302.

-Kesseler M, Dabbs ER, Averhoff B, Gottschalk G: Studies on the isopropylbenzene 2,3-dioxygenase and the 3-isopropylcatechol 2,3dioxygenase genes encoded by the linear plasmid of Rhodococcus erythropolis BD2. Microbiology 1996;142:3241-3251.

- Khan AA, Wang RF, Cao WW, Doerge DR, Wennerstrom D, Cerniglia CE: Molecular cloning, nucleotide sequence, and expression of genes encoding a polcyclic aromatic ring dioxygenase from Mycobacterium sp strain PYR-1. Appl Environ Microbiol 2001; 67:3577-3585.

Kiefer PM, Copley SD: Characterization of the initial steps in the reductive dehalogenation catalyzed by tetrachlorohydroquinone dehalogenase. Biochemistry 2002;41:13151322.

Kikuchi Y, Yasukochi Y, Nagata Y, Fukuda M, Takagi M: Nucleotide sequence and functional analysis of the meta-cleavage pathway involved in biphenyl and polychlorinated biphenyl degradation in Pseudomonas sp. strain KKS102. J Bacteriol 1994;176:42694276.

Kim E, Zylstra GJ: Functional analysis of genes involved in biphenyl, naphthalene, phenanthrene, and m-xylene degradation by Sphingomonas yanoikuyae B1. J Ind Microbiol Biotechnol 1999;23:294-302.

-Kimbara K, Hashimoto T, Fukuda M, Koana T, Takagi M, Oishi M, Yano K: Cloning and sequencing of two tandem genes involved in degradation of 2,3-dihydroxybiphenyl to benzoic acid in the polychlorinated biphenyl-degrading soil bacterium Pseudomonas sp. strain KKS102. J Bacteriol 1989;171: 2740-2747.
Kimura N, Nishi A, Goto M, Furukawa K: Functional analyses of a variety of chimeric dioxygenases constructed from two biphenyl dioxygenases that are similar structurally but different functionally. J Bacteriol 1997; 179:3936-3943.

Kitagawa W, Suzuki A, Hoaki T, Masai E, Fukuda M: Multiplicity of aromatic ring hydroxylation dioxygenase genes in a strong PCB degrader, Rhodococcus sp. strain RHA1 demonstrated by denaturing gradient gel electrophoresis. Biosci Biotechnol Biochem 2001;65:1907-1911.

Klages U, Lingens F: Degradation of 4-chlorobenzoic acid by a Nocardia species. FEMS Microbiol Lett 1979;6:201-203.

Krumholz LR: Desulfuromonas chloroethenica sp. nov. uses tetrachloroethylene and trichloroethylene as electron acceptors. Int J Syst Bacteriol 1997;47:1262-1263.

Kulaev I, Kulakovskaya T: Polyphosphate and phosphate pumps. Annu Rev Microbiol 2000;54:709-734.

-Kumamaru T, Suenaga H, Mitsuoka M, Watanabe T, Furukawa K: Enhanced degradation of polychlorinated biphenyls by directed evolution of biphenyl dioxygenase. Nat Biotechnol 1998;16:663-666.

Labbe D, Garnon J, Lau PCK: Characterization of the genes encoding a receptor-like histidine kinase and a cognate response regulator from a biphenyl/polychlorobiphenyldegrading bacterium, Rhodococcus sp. strain M5. J Bacteriol 1997;179:2772-2776.

Larkin MJ, Allen CCR, Kulakov LA, Lipscomb DA: Purification and characterization of a novel naphthalene dioxygenase from Rhodococcus sp. strain NCIMB12038. J Bacteriol 1999;181:6200-6204.

Lee J, Min KR, Kim Y-C, Kim C-K, Lim J-Y, Yoon H, Min K-H, Lee K-S, Kim Y: Cloning of salicylate hydroxylase gene and catechol 2,3dioxygenase gene and sequencing of an intergenic sequence between the two genes of Pseudomonas putida KF715. Biochem Biophys Res Commun 1995;211:382-388.

Li JJ, Li C, Blindauer CA, Bugg THD: Evidence for a gem-diol reaction intermediate in bacterial C-C hydrolase enzymes $\mathrm{BphD}$ and MphC from 13C NMR spectroscopy. Biochemistry 2006a;45:12461-12469.

Li C, Li JJ, Montgomery MG, Wood SP, Bugg THD: Catalytic role for arginine 188 in the C-Chydrolase catalytic mechanism for Escherichia coli MphC and Burkholderia xenovorans $\mathrm{LB} 400 \mathrm{BphD}$. Biochemistry 2006b;45: 12470-12479.

Lloyd-Jones G, Ogden RC, Williams PA: Inactivation of 2,3-dihydroxybiphenyl 1,2-dioxygenase from Pseudomonas sp. strain CB406 by 3,4-dihydroxybiphenyl (4-phenylcatechol). Biodegradation 1995;6:11-17.

Lunt D, Evans WC: The microbial metabolism of biphenyl. Biochem J 1970;118:54-55.
Magnuson JK, Romine MF, Burris DR, Kingsley MT: Trichloroethene reductive dehalogenase from Dehalococcoides ethenogenes: sequence of $t c e A$ and substrate range characterization. Appl Environ Microbiol 2000;66: 5141-5147.

- Mars AE, Kasberg T, Kaschabek SR, van Agteren $\mathrm{MH}$, Janssen DB, Reineke W: Microbial degradation of chloroaromatics: use of the metacleavage pathway for mineralization of chlorobenzene. J Bacteriol 1997;179:4530-4537.

- Martínez P, Agulló L, Hernández M, Seeger M: Chlorobenzoate inhibits growth and induces stress proteins in the PCB-degrading bacterium Burkholderia xenovorans LB400. Arch Microbiol 2007;188:289-297.

Masai E, Yamada A, Healy JM, Hatta T, Kimbara K, Fukuda M, Yano K: Characterization of biphenyls catabolic genes of gram-positive polychlorinated biphenyls degrader Rhodococcus sp. strain RHA1. Appl Environ Microbiol 1995;61:2079-2085.

- May HD, Cutter LA, Miller GS, Milliken CE, Watts JE, Sowers KR: Stimulatory and inhibitory effects of organohalides on the dehalogenating activities of PCB-dechlorinating bacterium o-17. Environ Sci Technol 2006; 40:5704-5709.

Mayes BA, McConnell EE, Neal BH, Brunner MJ, Hamilton SB, Sullivan TM, Peters AC, Ryan MJ, Toft JD, Singer AW, Brown JF, Menton RG, Moore JA: Comparative carcinogenicity in Sprague-Dawley rats of the polychlorinated biphenyl mixtures aroclors 1016, 1242, 1254, and 1260. Toxicol Sci 1998; 41:62-76.

Maymo-Gatell X, Anguish T, Zinder SH: Reductive dechlorination of chlorinated ethenes and 1,2-dichloroethane by 'Dehalococcoides ethenogenes' 195. Appl Environ Microbiol 1999;65:3108-3113.

-McKay DB, Prucha M, Reineke W, Timmis KN, Pieper DH: Substrate specificity and expression of three 2,3-dihydroxybiphenyl 1,2-dioxygenases from Rhodococcus globerulus strain P6. J Bacteriol 2003;185:2944-2951.

McKay DB, Seeger M, Zielinski M, Hofer B, Timmis KN: Heterologous expression of biphenyl dioxygenase-encoding genes from a gram-positive broad-spectrum polychlorinated biphenyl degrader and characterization of chlorobiphenyl oxidation by the gene products. J Bacteriol 1997;179:1924-1930.

McLeod MP, Warren RL, Hsiao WW, Araki N, Myhre M, Fernandes C, Miyazawa D, Wong W, Lillquist AL, Wang D, Dosanjh M, Hara H, Petrescu A, Morin RD, Yang G, Stott JM, Schein JE, Shin H, Smailus D, Siddiqui AS, Marra MA, Jones SJ, Holt R, Brinkman FS, Miyauchi K, Fukuda M, Davies JE, Mohn WW, Eltis LD: The complete genome of Rhodococcus sp. RHA1 provides insights into a catabolic powerhouse. Proc Natl Acad Sci USA 2006;103:15582-15587. 
-Merlin C, Springael D, Mergeay M, Toussaint A: Organisation of the $b p h$ gene cluster of transposon Tn4371, encoding enzymes for the degradation of biphenyl and 4-chlorobiphenyl compounds. Mol Gen Genet 1997;253: 499-506.

- Merlin C, Springael D, Toussaint A: Tn4371:A modular structure encoding a phage-like integrase, a Pseudomonas-like catabolic pathway, and RP4/Ti-like transfer functions. Plasmid 1999:40-54.

-Mohn WW, Tiedje JM: Strain DCB-1 conserves energy for growth from reductive dechlorination coupled to formate oxidation. Arch Microbiol 1990;153:267-271.

-Mohn WW, Tiedje JM: Evidence for chemiosmotic coupling of reductive dechlorination and ATP synthesis in Desulfomonile tiedjei. Arch Microbiol 1991;157:1-6.

- Moiseeva OV, Solyanikova IP, Kaschabek SR, Groning J, Thiel M, Golovleva LA, Schlömann M: A new modified ortho cleavage pathway of 3-chlorocatechol degradation by Rhodococcus opacus 1CP: genetic and biochemical evidence. J Bacteriol 2002;184: 5282-5292.

-Mondello FJ: Cloning and expression in Escherichia coli of Pseudomonas strain LB400 genes encoding polychlorinated biphenyl degradation. J Bacteriol 1989;171:17251732.

Mondello FJ, Turcich MP, Lobos JH, Erickson BD: Identification and modification of biphenyl dioxygenase sequences that determine the specificity of polychlorinated biphenyl degradation. Appl Environ Microbiol 1997;63:3096-3103.

-Mouz S, Merlin C, Springael D, Toussaint A: A GntR-like negative regulator of the biphenyl degradation genes of the transposon Tn 4371 . Mol Gen Genet 1999;262:790-799.

- Mukerjee-Dhar G, Shimura M, Miyazawa D, Kimbara K, Hatta T: $b p h$ genes of the thermophilic PCB degrader, Bacillus sp. JF8: characterization of the divergent ring-hydroxylating dioxygenase and hydrolase genes upstream of the Mn-dependent BphC. Microbiology 2005;151:4139-4151.

Nakatsu C, Wyndham RC: Cloning and expression of the transposable chlorobenzoate-3,4dioxygenase genes of Alcaligenes sp. BR60. Appl Environ Microbiol 1993;59:36253633.

Nardini M, Dijkstra BW: $\alpha / \beta$-Hydrolase fold enzymes: the family keeps growing. Curr Opin Struct Biol 1999;9:732-737.

-Nikodem P, Hecht V, Schlömann M, Pieper DH: New bacterial pathway for 4- and 5-chlorosalicylate degradation via 4-chlorocatechol and maleylacetate in Pseudomonas sp. strain MT1. J Bacteriol 2003;185:6790-6800.

-Nishi A, Tominaga K, Furukawa K: A 90-kilobase conjugative chromosomal element coding for biphenyl and salicylate catabolism in Pseudomonas putida KF715. J Bacteriol 2000;182:1949-1955.

Bacterial Metabolism of Polychlorinated Biphenyls
Noda Y, Nishikawa S, Shiozuka KI, Kadokuda H, Nakajima H, Yoda K, Katayama Y, Morohoshi N, Haraguchi T, Yamasaki M: Molecular cloning of the protocatechuate 4,5-dioxygenase genes of Pseudomonas paucimobilis. J Bacteriol 1990;172:2704-2709.

Nogales B, Moore ERB, Abraham WR, Timmis $\mathrm{KN}$ : Identification of the metabolically active members of a bacterial community in a polychlorinated biphenyl polluted moorland soil. Environ Microbiol 1999;1:199-212.

- Nojiri H, Nam JW, Kosaka M, Morii KI, Takemura T, Furihata K, Yamane H, Omori T: Diverse oxygenations catalyzed by carbazole 1,9a-dioxygenase from Pseudomonas sp. strain CA10. J Bacteriol 1999;181:3105-3113. Ohnishi K, Okuta A, Ju JS, Hamada T, Misono $\mathrm{H}$, Harayama S: Molecular breeding of 2,3dihydroxybiphenyl 1,2-dioxygenase for enhanced resistance to 3-chlorocatechol. J Biochem 2004;135:305-317.

- Ohta Y, Maeda M, Kudo T: Pseudomonas putida CE2010 can degrade biphenyl by a mosaic pathway encoded by the tod operon and $c m t E$, which are identical to those of $P$. putida F1 except for a single base difference in the operator-promoter region of the cmt operon. Microbiology 2001;147:31-41.

Ohtsubo Y, Delawary M, Kimbara K, Takagi M, Ohta A, Nagata Y: BphS, a key transcriptional regulator of bph genes involved in polychlorinated biphenyl/biphenyl degradation in Pseudomonas sp. KKS102. J Biol Chem 2001;276:36146-36154.

Ollis DL, Cheah E, Cygler M, Dijkstra B, Frolow F, Franken SM, Harel M, Remington SJ, Silman I, Schrag J, Sussman JL, Verschueren KHG, Goldman A: The $\alpha / \beta$ hydrolase fold. Protein Eng 1992;5:197-211.

Park S, Oh K, Kim C: Adaptive and cross-protective responses of Pseudomonas sp. DJ-12 to several aromatics and other stress shocks. Curr Microbiol 2000;43:176-181.

- Parnell JJ, Park J, Denef V, Tsoi T, Hashsham S, Quensen J III, Tiedje JM: Coping with polychlorinated biphenyl (PCB) toxicity: physiological and genome-wide responses of Burkholderia xenovorans LB400 to PCB-mediated stress. Appl Environ Microbiol 2006; 72:6607-6614.

Patel TR, Gibson DT: Purification and properties of (+)-cis-naphthalene dihydrodiol dehydrogenase of Pseudomonas putida. J Bacteriol 1974;119:879-888.

Peloquin L, Greer CW: Cloning and expression of the polychlorinated biphenyl-degradation gene cluster from Arthrobacter M5 and comparison to analogous genes from gram-negative bacteria. Gene 1993;125:35-40.

- Pieper DH: Aerobic degradation of polychlorinated biphenyls. Appl Microbiol Biotechnol 2005;67:170-191.

Rabus R, Kube M, Heider J, Beck A, Heitmann $\mathrm{K}$, Widdel F, Reinhardt R: The genome sequence of an anaerobic aromatic-degrading denitrifying bacterium, strain EbN1. Arch Microbiol 2005;183:27-36.
Raschke H, Fleischmann T, van der Meer JR, Kohler HPE: cis-Chlorobenzene dihydrodiol dehydrogenase (TcbB) from Pseudomonas sp strain P51, expressed in Escherichia coli DH5 alpha(PTCB149), catalyzes enantioselective dehydrogenase reactions. Appl Environ Microbiol 1999;65:5242-5246.

- Raschke H, Meier M, Burken JG, Hany R, Muller MD, Van der Meer JR, Kohler HPE: Biotransformation of various substituted aromatic compounds to chiral dihydrodihydroxy derivatives. Appl Environ Microbiol 2001;67:3333-3339.

Rogers JE, Gibson DT: Purification and properties of cis-toluene dihydrodiol dehydrogenase from Pseudomonas putida. J Bacteriol 1977;130:1117-1124.

Romine MF, Stillwell LC, Wong KK, Thurston SJ, Sisk EC, Sensen C, Gaasterland T, Fredrickson JK, Saffer JD: Complete sequence of a 184-kilobase catabolic plasmid from Sphingomonas aromaticivorans F199. J Bacteriol 1999;181:1585-1602.

-Sanford RA, Cole JR, Loffler FE, Tiedje JN: Characterization of Desulfitobacterium chlororespirans sp nov, which grows by coupling the oxidation of lactate to the reductive dechlorination of 3-chloro-4-hydroxybenzoate. Appl Environ Microbiol 1996;62:38003808.

Seah SYK, Labbe G, Kaschabek SR, Reifenrath F, Reineke W, Eltis LD: Comparative specificities of two evolutionarily divergent hydrolases involved in microbial degradation of polychlorinated biphenyls. J Bacteriol 2001; 183:1511-1516.

- Seah SYK, Labbe G, Nerdinger S, Johnson MR, Snieckus V, Eltis LD: Identification of a serine hydrolase as a key determinant in the microbial degradation of polychlorinated biphenyls. J Biol Chem 2000;275:1570115708.

-Seeger M, Cámara B, Hofer B: Dehalogenation, denitration, dehydroxylation, and angular attack on substituted biphenyls and related compounds by a biphenyl dioxygenase. J Bacteriol 2001;183:3548-3555.

-Seeger M, Gonzalez M, Cámara B, Muñoz L, Ponce E, Mejiás L, Mascayano C, Vásquez Y, Sepúlveda-Boza S: Biotransformation of natural and synthetic isoflavonoids by two recombinant microbial enzymes. Appl Environ Microbiol 2003;69:5045-5050.

- Seeger M, Timmis KN, Hofer B: Conversion of chlorobiphenyls into phenylhexadienoates and benzoates by the enzymes of the upper pathway for polychlorobiphenyl degradation encoded by the $b p h$ locus of Pseudomonas sp. strain LB400. Appl Environ Microbiol 1995a;61:2654-2658.

- Seeger M, Timmis KN, Hofer B: Degradation of chlorobiphenyls catalyzed by the $b p h$-encoded biphenyl-2,3-dioxygenase and biphenyl-2,3-dihydrodiol-2,3-dehydrogenase of Pseudomonas sp. LB400. FEMS Microbiol Lett 1995b;133:259-264.

\section{Biphenyls}


-Seeger M, Timmis KN, Hofer B: Bacterial pathways for the degradation of polychlorinated biphenyls. Marine Chem 1997;58:327-333.

-Seeger M, Zielinski M, Timmis KN, Hofer B: Regiospecificity of dioxygenation of di- to pentachlorobiphenyls and their degradation to chlorobenzoates by the $b p h$-encoded catabolic pathway of Burkholderia sp. strain LB400. Appl Environ Microbiol 1999;65: 3614-3621.

- Sericano JL, Wade TL, Jackson TJ, Brooks JM, Tripp BW, Farrington LD, Mee LD, Readmann JW, Villeneuve JP, Goldberg ED: Trace organic contamination in the Americas: an overview of the US National Status and Trends and the International Mussel Watch programmes. Mar Pollut Bull 1995;31:214225.

- Seshadri R, Adrian L, Fouts DE, Eisen JA, Phillippy AM, Methe BA, Ward NL, Nelson WC, Deboy RT, Khouri HM, Kolonay JF, Dodson RJ, Daugherty SC, Brinkac LM, Sullivan SA, Madupu R, Nelson KE, Kang KH, Impraim M, Tran K, Robinson JM, Forberger HA, Fraser CM, Zinder SH, Heidelberg JF: Genome sequence of the PCE-dechlorinating bacterium Dehalococcoides ethenogenes. Science 2005;307:105-108.

Seto M, Kimbara K, Shimura M, Hatta T, Fukuda M, Yano K: A novel transformation of polychlorinated biphenyls by Rhodococcus sp. strain RHA1. Appl Environ Microbiol 1995; 61:3353-3358.

- Sikkema J, de Bont JAM, Poolman B: Mechanisms of membrane toxicity of hydrocarbons. Microbiol Rev 1995;59:201-222.

-Sondossi M, Sylvestre M, Ahmad D: Effects of chlorobenzoate transformation on the Pseudomonas testosteroni biphenyl and chlorobiphenyl degradation pathway. Appl Environ Microbiol 1992;58:485-495.

-Springael D, Kreps S, Mergeay M: Identification of a catabolic transposon, Tn4371, carrying biphenyl and 4-chlorobiphenyl degradation genes in Alcaligenes eutrophus A5. J Bacteriol 1993;175:1674-1681.

-Stecker C, Johann A, Herzberg C, Averhoff B, Gottschalk G: Complete nucleotide sequence and genetic organization of the 210-kilobase linear plasmid of Rhodococcus erythropolis BD2. J Bacteriol 2003;185:5269-5274.

-Suenaga H, Nishi A, Watanabe T, Sakai M, Furukawa K: Engineering a hybrid pseudomonad to acquire 3,4-dioxygenase activity for polychlorinated biphenyls. J Biosci Bioeng 1999; 87:430-435.

-Suenaga H, Watanabe T, Sato M, Ngadiman, Furukawa $\mathrm{K}$ : Alteration of regiospecificity in biphenyl dioxygenase by active-site engineering. J Bacteriol 2002;184:3682-3688.
Taguchi K, Motoyama M, Kudo T: Multiplicity of 2,3-dihydroxybiphenyl dioxygenase genes in the Gram-positive polychlorinated biphenyl degrading bacterium Rhodococcus rhodochrous K37. Biosci Biotechnol Biochem 2004;68:787-795.

Takeda H, Yamada A, Miyauchi K, Masai E, Fukuda M: Characterization of transcriptional regulatory genes for biphenyl degradation in Rhodococcus sp. strain RHA1. J Bacteriol 2004; 186:2134-2146.

Taylor PM, Janssen PH: Variations in the abundance and identity of class II aromatic ringhydroxylating dioxygenase genes in groundwater at an aromatic hydrocarbon-contaminated site. Environ Microbiol 2005;7:140146.

- Taylor PM, Medd JM, Schoenborn L, Hodgson B, Janssen PH: Detection of known and novel genes encoding aromatic ring- hydroxylating dioxygenases in soils and in aromatic hydrocarbon-degrading bacteria. FEMS Microbiol Lett 2002;216:61-66.

Tocheva E, Fortin PD, Eltis LD, MEP M: Structures of ternary complexes of BphK, a bacterial glutathione $S$-transferase that reductively dechlorinates polychlorinated biphenyl metabolites. J Biol Chem 2006;281:3093330940.

Toussaint A, Merlin C, Monchy S, Benotmane MA, Leplae R, Mergeay M, Springael D: The biphenyl- and 4-chlorobiphenyl-catabolic transposon Tn4371, a member of a new family of genomic islands related to IncP and $\mathrm{Ti}$ plasmids. Appl Environ Microbiol 2003;69: 4837-4845.

Vaillancourt FH, Bolin JT, Eltis LD: Ring-cleavage dioxygenases; in Ramos JL (ed): The Pseudomonads, vol III. New York: Kluwer Academic/Plenum, 2003, pp 1253-1260.

Vaillancourt FH, Labbe G, Drouin NM, Fortin PD, Eltis LD: The mechanism-based inactivation of 2,3-dihydroxybiphenyl 1,2- dioxygenase by catecholic substrates. J Biol Chem 2002;277:2019-2027.

van der Ploeg J, Smidt MP, Landa AS, Janssen DB: Identification of chloroacetaldehyde dehydrogenase involved in 1,2-dichloroethane degradation. Appl Environ Microbiol 1994; 60:1599-1605.

Vezina J, Barriault D, Sylvestre M: Family shuffling of soil DNA to change the regiospecificity of Burkholderia xenovorans LB400 biphenyl dioxygenase. J Bacteriol 2007;189: 779-788.

Visser FR, Lane G: Selectivity of the hydrogenation of 2',4',7-tribenzyloxyisoflavone. Aust J Chem 1987;40:1705-1711.

Warner JR, Lawson SL, Copley SD: A mechanistic investigation of the thiol-disulfide exchange step in the reductive dehalogenation catalyzed by tetrachlorohydroquinone dehalogenase. Biochemistry 2005;44:1036010368.
Watanabe T, Inoue R, Kimura N, Furukawa K: Versatile transcription of biphenyl catabolic bph operon in Pseudomonas pseudoalcaligenes KF707. J Biol Chem 2000;275:3101631023.

Wiegel J, Wu QZ: Microbial reductive dehalogenation of polychlorinated biphenyls. FEMS Microbiol Ecol 2000;32:1-15.

Williams P, Sayers J: The evolution of pathways for aromatic hydrocarbon oxidation in $\mathrm{Pseu}$ domonas. Biodegradation 1994;5:195-217.

-Witzig R, Junca H, Hecht HJ, Pieper DH: Assessment of toluene/biphenyl dioxygenase gene diversity in benzene-polluted soils: links between benzene biodegradation and genes similar to those encoding isopropylbenzene dioxygenases. Appl Environ Microbiol 2006; 72:3504-3514.

-Wu Q, Watts JE, Sowers KR, May HD: Identification of a bacterium that specifically catalyzes the reductive dechlorination of polychlorinated biphenyls with doubly flanked chlorines. Appl Environ Microbiol 2002;68:807812.

Yamada A, Kishi H, Sugiyama K, Hatta T, Nakamura K, Masai E, Fukuda M: Two nearly identical aromatic compound hydrolase genes in a strong polychlorinated biphenyl degrader, Rhodococcus sp. strain RHA1. Appl Environ Microbiol 1998;64:20062012.

-Yan T, Lapara TM, Novak PJ: The reductive dechlorination of 2,3,4,5-tetrachlorobiphenyl in three different sediment cultures: evidence for the involvement of phylogenetically similar Dehalococcoides-like bacterial populations. FEMS Microbiol Ecol 2006;55: 248-261.

Yu C, Liu W, Ferraro D, Brown E, Parales JV, Ramaswamy S, Zylstra GJ, Gibson DT, Parales RE: Purification, characterization and crystallization of the components of a biphenyl dioxygenase system from Sphingobium yanoikuyae B1. J Ind Microbiol Biotechnol 2007;34:311-324.

-Zaar A, Eisenreich W, Bacher A, Fuchs G: A novel pathway of aerobic benzoate catabolism in the bacteria Azoarcus evansii and Bacillus stearothermophilus. J Biol Chem 2001;276: 24997-25004.

Zielinski M, Kahl S, Standfuss-Gabisch C, Cámara B, Seeger M, Hofer B: Generation of novel-substrate-accepting biphenyl dioxygenases through segmental random mutagenesis and identification of residues involved in enzyme specificity. Appl Environ Microbiol 2006;72:2191-2199.

Zylstra GJ, Kim E: Aromatic hydrocarbon degradation by Sphingomonas yanoikuyae B1. J Ind Microbiol Biotechnol 1997;19:408-414. 